\title{
A review of Tabellaria species from freshwater environments in Europe
}

\author{
David Heudre $^{1 *}$, Carlos E. Wetzel ${ }^{2}$, Horst Lange-Bertalot ${ }^{3}$, Bart Van de \\ VIJVER $^{4,5}$, Laura MOREAU ${ }^{1} \&$ Luc ECTOR $^{2}$
}

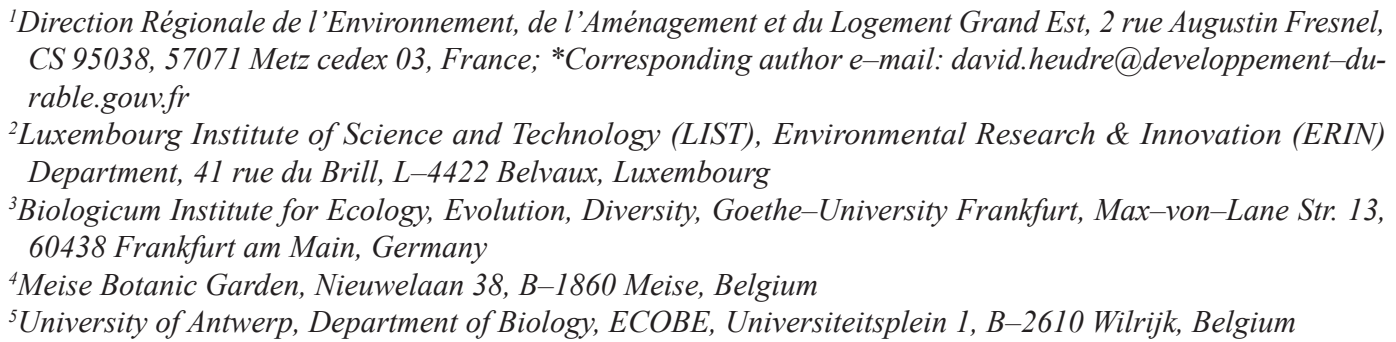

\begin{abstract}
The diatom genus Tabellaria Ehrenberg is one of the most widely distributed genera in freshwaters, both in benthos and phytoplankton. It is rather frequent in unpolluted, circumneutral to slightly acidic and poorly mineralized lakes, streams and peat bogs. Despite being studied intensively in the last decades, the taxonomy of this genus is still unsatisfactory as some authors recently proposed to consider most species as synonyms of Tabellaria flocculosa (Roth) Kützing. Several dozen of Tabellaria rich samples from Europe were investigated and six were selected to illustrate typical populations. Five new species are described based on detailed LM and SEM observations: Tabellaria acidodelicata sp. nov., Tabellaria hercynica sp. nov., Tabellaria koppeniana sp. nov., Tabellaria procera sp. nov. and Tabellaria valdeventricosa sp. nov. Additionally, the type materials of $T$. fenestrata, T. flocculosa and T. ventricosa have been investigated and illustrated together with a discussion on Tabellaria andina stat. nov., at present exclusively found in South America.
\end{abstract}

Key words: electron microscopy, morphology, new species, Tabellaria, taxonomy, type material

\section{INTRODUCTION}

The diatom genus Tabellaria Ehrenberg ex Kützing is one of the most widely distributed genera in freshwaters, both in benthos and phytoplankton (Round et al. 1990). It is rather frequent in unpolluted, circumneutral to slightly acidic and poorly mineralized lakes, streams and peat bogs. Moreover, a Tabellaria species is the very first diatom to have been illustrated as early as 1703 by the naturalist Charles King (DoLAN 2019) but without being given a name [according to KNUDSON (1952) it was most likely Tabellaria flocculosa (Roth) Kützing]. However, despite being intensively studied in the past decades (e.g. KnUdson 1952; Koppen 1975; Germain 1987; LANGE-Bertalot 1988; Krammer \& LANGE-Bertalot 1991), the taxonomy of the genus is still unsatisfactory and the complex taxonomical history of T. flocculosa, probably the most common and "well-known" taxon of this genus in Europe, is emblematic of this.

The name Tabellaria was used for the first time by EHRENBERG (1840) with the description of two new species: Tabellaria amphicephala Ehrenberg and Tabellaria trinodis Ehrenberg. However, the genus proved initially to be invalid due to a missing description, an error corrected a few years later by KüTZING (1844). The diagnosis is then accompanied by the description of Tabellaria ventricosa Kützing and the transfer of Conferva flocculosa Roth and Diatoma fenestrata Lyngbye to the genus Tabellaria. Subsequently, almost 20 varieties of T. flocculosa have been described by authors in different periods, although no one examined in detail the original material used by A.W. Roth. The latter proved to be unfindable, which led to the designation of Eulenstein's Diat. spec. typ. No. 50 material housed in the British Museum as a neotype by KNUDSON (1952). Later, KopPen (1975) added three morphological strains to Tabellaria flocculosa. Finally, the study of several Russian Tabellaria populations led Genkal \& CHeKryzheva (2016) to conclude that the following taxa should be considered being heterotypic synonyms of $T$. flocculosa: Tabellaria fenestrata, Tabellaria quadriseptata and T. ventricosa, together with all their varieties (including those of T. flocculosa). Unfortunately, 
this grouping was not based on the examination of any type material of the latter species and this vision is therefore not shared by many authors (see for instance LANGE-BERTALOT et al. 2017). This historical trend has led to a very broad interpretation of T. flocculosa with variations in morphology and ecology between different authors (FABRI \& LECLERCQ 1984; FlOWER \& BATTARBEE 1985; GERMAIN 1987; LANGE-BERTALOT 1988; KramMER \& LANGe-Bertalot 1991; CAMburn \& Charles 2000; Siver et al. 2005; ANTONiADES et al. 2008; HofmAnn et al. 2011; ECTOR et al. 2015; LANGE-BERTALOt et al. 2017).

The aim of the present paper is to improve our understanding of the genus Tabellaria in Europe. Several dozens of Tabellaria-rich samples from Europe were investigated and separation criteria asserted. Among these samples, six were selected to illustrate typical populations of European taxa. Five new species are described based on detailed LM and SEM observations: Tabellaria acidodelicata sp. nov., Tabellaria hercynica sp. nov., Tabellaria koppeniana sp. nov., Tabellaria procera sp. nov. and Tabellaria valdeventricosa sp. nov. Additionally, the type material of $T$. fenestrata, T. flocculosa and $T$. ventricosa has been investigated and illustrated. Tabellaria andina stat. nov., a taxon from South America based on Tabellaria flocculosa var. andina Lange-Bertalot, is likewise split off from Tabellaria flocculosa.

\section{Material ANd Methods}

Populations were collected from phytoplankton samples, hard mineral substrates (stones) or stems of macrophytes in lakes and rivers all across Europe (see Table 1). Subsamples were cleaned by adding hot $37 \%$ hydrogen peroxide $\left(\mathrm{H}_{2} \mathrm{O}_{2}\right)$ and hydrochloric acid $(\mathrm{HCl})$, and rinsed three times with distilled water. For light microscopy observations, the material was diluted with distilled water to avoid excessive concentrations of diatom valves. Cleaned diatom valves were mounted in Naphrax. The slides were analysed at $1000 \times$ magnification using an Olympus BX53 microscope, equipped with Differential Interference Contrast (Nomarski) and a Jenoptik ProgRes Speed XT3 camera. For the biometric data, the number of specimens (n) measured at random on the slides is indicated. Mean and standard deviation values of length and width are calculated and provided. The stria density was measured on $10 \mu \mathrm{m}$ with exclusion of the central area. Median values of striae are calculated and provided. For scanning electron microscopy (SEM), parts of the oxidized suspensions were filtered with additional deionized water through a $3 \mu \mathrm{m}$ Isopore ${ }^{\mathrm{TM}}$ polycarbonate membrane filter (Merck Millipore), pieces of which were fixed on aluminum stubs after air-drying. The stubs were coated with platinum using a Modular High Vacuum Coating System BAL-TEC MED 020 (BAL-TEC AG, Balzers, Liechtenstein), and studied in an ultra-high-resolution analytical field emission (FE) scanning electron microscope, Hitachi SU-70 (Hitachi High-Technologies Corporation, Japan), operated at $5 \mathrm{kV}$ and $10 \mathrm{~mm}$ distance. SEM images were taken using the lower (SE-L) detector signal and a tilting of up to $28^{\circ}$. Micrographs were digitally manipulated and plates containing light and scanning electron microscopy images were created using CorelDraw X8®. Boxplot and scatter plot graphics were made using R version 3.5.3 (R CORE TEAm 2019) and RStudio version 1.3.1073. Linear discriminant analysis and other statistical tests were made using the PAST software version 4.05 (Hammer et al. 2001). Computer assisted outline shape description was made using SHERPA software (KLOSTER et al. 2014). 257 specimen's photos from all the types materials were analysed, segmentations were manually reworked for better accuracy and 13 outlines descriptors of each photos were recovered for further analysis: length, width, rectangularity, compactness, ellipticity, triangularity, roundness, convexity by perimeter, convexity by area, formfactor, Convexity Defect Factor (CDF), Percent Concave Area Fraction (PCAF) and Convex Hull Maximum Distance Factor (CHMDF).

Four letters acronyms used in figures correspond to the following species: Tabellaria acidodelicata (TACD), $T$. procera (TAPR), T. fenestrata (TFEN), T. flocculosa (TFLO), T. hercynica (THER), T. koppeniana (TKOP), T. ventricosa (TVEN) and T. valdeventricosa (TVVE).

For this study, the isoneotype material of Tabellaria flocculosa, Diat. Spec. typ. No. 50 "In Aqua Dulci Naes Norvegia" from the Eulenstein collection (Meise Botanic Garden, Belgium), the original material of Tabellaria ventricosa (sample Kützing 752 from Falaise, France) from the Kützing collection (Meise Botanic Garden, Belgium) and the original material of Diatoma fenestrata Lyngbye collection from the Universitets botanishke Museum in Copenhagen (Denmark) were investigated and illustrated. As the conserved original material of Diatoma fenestrata in the Lyngbye collection was already treated material, a second treatment resulted in the break-up of all frustules making it impossible to find intact frustules. Therefore, an additional sample showing a population representative of the type (Unnamed pond near Eckenthal, France) was therefore chosen to illustrate girdle views and filaments of this taxon. Table 1 summarize the samples used in the present manuscript.

\section{RESULTS}

A total of eight Tabellaria taxa have been identified and are here illustrated. For each taxon, a short discussion on its morphological and taxonomical characteristics with references to useful identification literature is provided. Based on the morphological analysis using both LM and SEM observations, five taxa could not be identified using the currently available literature and are described as new to science. Fig. 1 and Table 2 summarize the morphometric and morphological features of all Tabellaria species studied. The eight taxa identified in this study share features such as mostly septate copulae, colonies formed by frustules attached using mucilage pads, and cells with numerous discoid or slightly elongated plastids located between the septa.

Tabellaria fenestrata (Lyngbye) Kützing (Figs 2-34, S1-S10)

References: LyNGBYE 1819, p. 180, pl. 61, fig. E3; KÜTZING 1844, p. 127, pl. 30, fig. 73, non pl. 17, fig. 22; KNUDSON 1952, p. 423, fig. 1A-C; Koppen 1975, figs 5, 6, 13, 14, 17, 27-29; LANGE-Bertalot 1988, p. 415 , pl. 2, figs $1-5$, pl. 5, figs 7, 8; Krammer \& LANGe-Bertalot 1991 , p. 106 , pl. 105 , figs $1-4$, pl. 107, fig. 8; KoBAYASI et al. 2006, p. 90, pl. 108, figs 1-11, pl. 109, figs 12-17; HofmanN et al. 2011, p. 
562, pl. 3, figs 14-16; DeColibus 2013a, figs 1-7; Lange-Bertalot et al. 2017 , p. 589 , pl. 4 , figs $15-17$.

Morphometric data $(\mathrm{n}=30$, pond near Eckenthal): length 48-71 $\mu \mathrm{m}$ (average 61.5 $\pm 5.5 \mu \mathrm{m}$ ); width 6.0-7.5 $\mu \mathrm{m}$ (average $6.9 \pm 0.4 \mu \mathrm{m}$ ); stria density $16-20$ in $10 \mu \mathrm{m}$ (median 18).

Remarks: Tabellaria fenestrata is easily distinguishable from other species by having three inflations approximately equal in width (proximal width / apical width ratio around 1.1; see Fig. 1 and Table 2), high length to width ratio (7-10), two to four septa in girdle view (Figs 30, 31), open septa bands and copulae (Figs 12, $21,32,33)$ and linear colonies with cells joined at an angle of around $180^{\circ}$ when observed in untreated material (Fig. 34). However, simple stellate formations may occur as illustrated by ZACH (1979, fig. 6) and KoBAYASI et al. (2006, pl. 108, fig. 9). Small sharp spines can be observed on the valve face/mantle junction when analysed in SEM (Figs 13-16). In type material and other studied populations, areolae are almost always rimmed by donut-like structures (Figs 13-15, S1, S3-S6, S10; Krammer \& LANGe-Bertalot 1991, pl. 107, fig. 8). However this feature may be proved non distinctive as other authors didn't noticed them (e.g. KoBAYASI et al. 2006, pl. 108, figs 10, 11). In many populations studied the exact position of the rimoportula in the proximal inflation seems variable (Figs 2-11, 22-29). The total length range observed by LYNGBYE (1819) is 25-116 $\mu \mathrm{m}$, but in type material and other populations studied the actual length range is only $40-75 \mu \mathrm{m}$.

Tabellaria fenestrata was found in oligotrophic to mesotrophic, slightly acidic ponds and lakes, mainly attached to stones and Sphagnum. Abundant living populations ( 1 to $5 \%$ of the total diatom composition) were also found in the phytoplankton from the same lakes. In all studied samples, it most often co-occurred with Tabellaria flocculosa although always in lower relative abundances. In literature, very varied ecologies ranging from oligotrophic to eutrophic freshwaters could be found. This is probably due to identification problems and confusion with longer specimens of other Tabellaria species.

\section{Tabellaria flocculosa (Roth) Kützing (Figs 35-88, S11-S61)}

References: Rотн 1797, p. 192, pl. 4, fig. 4, pl. 5, fig. 6; KüTZING 1844, p. 127, pl. 17, fig. 21; KNUdSON 1952, p. 425, fig. 2A-I; KopPeN 1975, figs 4, 9, 10, 12, 16, 23-26, 30-33, 37-43; FLOWER \& BATTARBEE 1985, figs 2E-H, 3B, 3D, 4C-D, 5D; Lange-Bertalot 1988, p. 416, pl. 1, figs 9-11, pl. 4, figs 8, 9; Krammer \& Lange-Bertalot 1991, p. 108 , pl. 106, figs $6,8,9$, pl. 107, figs $7,11,12$; SIVER et al. 2005, p. 216, pl. 22, figs 13-18, 21, 22; KoBAYASI et al. 2006, p. 91, pl. 110, figs 1-14, pl. 111, figs 15-18; non ANTONIADES et al. 2008, p. 299, pl. 3 , figs 11-13 (specimens illustrated are atypical and could belong to Tabellaria hercynica sp. nov.); Hofmann et al. 2011, p. 563, pl. 3, figs 5, 6, 8; DeColibus 2013b, figs 3-11; ECTOR et al. 2015, p. 641-643; Lange-Bertalot et al. 2017, p. 590, pl. 4, figs 18, 20, 21; Peeters \& ECTOR 2017, p. 270, 20 figs.

Table 1. List of samples used for species discussed in the present manuscript. The symbol * shows coordinates that correspond to the main localities due to the lack of sampling site precise geolocation.

\begin{tabular}{|c|c|c|c|}
\hline Samples & Coordinates & Collected on & Species discussed \\
\hline Creek “Kleiner Rachelbach”, Frauenau (Germany) & $\begin{array}{l}12^{\circ} 23^{\prime} 17^{\prime \prime} \mathrm{E} \\
48^{\circ} 59^{\prime} 35^{\prime \prime} \mathrm{N}\end{array}$ & $\begin{array}{l}02 \text { November } \\
2004\end{array}$ & $\begin{array}{l}\text { Tabellaria acidodelicata } \\
\text { sp. nov. }\end{array}$ \\
\hline $\begin{array}{l}\text { "In a stream slowly flowing to Naes Norvegiae" from } \\
\text { Lyngbye collection (Universitetets botaniske Museum, } \\
\text { Copenhagen, Denmark) }\end{array}$ & $\begin{array}{l}06^{\circ} 39^{\prime} 38^{\prime \prime} \mathrm{E} \\
58^{\circ} 17^{\prime} 49^{\prime \prime} \mathrm{N} *\end{array}$ & Unknown & T. fenestrata \\
\hline Unnamed pond near Heckental (France) & $\begin{array}{l}7^{\circ} 29^{\prime} 26^{\prime \prime} \mathrm{E} \\
49^{\circ} 2^{\prime} 10^{\prime \prime} \mathrm{N}\end{array}$ & 23 August 2017 & T. fenestrata \\
\hline $\begin{array}{l}\text { Spec. typ. No. } 50 \text { "In Aqua Dulci Naes Norvegia" } \\
\text { from the Eulenstein collection (Meise Botanic Garden, } \\
\text { Belgium) }\end{array}$ & $\begin{array}{l}06^{\circ} 39^{\prime} 38^{\prime \prime} \mathrm{E} \\
58^{\circ} 17^{\prime} 49^{\prime \prime} \mathrm{N} *\end{array}$ & Unknown & T. flocculosa \\
\hline Gérardmer Lake, Gérardmer (France) & $\begin{array}{l}6^{\circ} 51^{\prime} 12^{\prime \prime} \mathrm{E} \\
48^{\circ} 4^{\prime} 1 " \mathrm{~N}\end{array}$ & 19 August 2015 & T. hercynica sp. nov. \\
\hline Rattån River, Kristinefors (Sweden) & $\begin{array}{l}12^{\circ} 54^{\prime} 19^{\prime \prime} \mathrm{E} \\
60^{\circ} 22^{\prime} 12^{\prime \prime} \mathrm{N}\end{array}$ & $\begin{array}{l}\text { 08 September } \\
2005\end{array}$ & T. koppeniana sp. nov. \\
\hline Cazaux Lake, La Teste-de-Buch (France) & $\begin{array}{l}1^{\circ} 11^{\prime} 58^{\prime \prime} \mathrm{O} \\
44^{\circ} 29^{\prime} 7^{\prime \prime} \mathrm{N}\end{array}$ & 10 August 2016 & T. procera sp. nov. \\
\hline Chaufour Stream, Grange-sur-Vologne (France) & $\begin{array}{l}6^{\circ} 51^{\prime} 4 " \mathrm{E} \\
48^{\circ} 6^{\prime} 12^{\prime \prime} \mathrm{N}\end{array}$ & 11 August 2018 & $\begin{array}{l}\text { T. valdeventricosa } \mathrm{sp} \text {. } \\
\text { nov. }\end{array}$ \\
\hline $\begin{array}{l}\text { Sample Kützing } 752 \text { from Falaise (France) from the } \\
\text { Kützing collection (Meise Botanic Garden, Belgium) }\end{array}$ & $\begin{array}{l}0^{\circ} 11^{\prime} 36 " \mathrm{O} \\
48^{\circ} 533^{\prime} 32^{\prime \prime} \mathrm{N} *\end{array}$ & Unknown & T. ventricosa \\
\hline
\end{tabular}




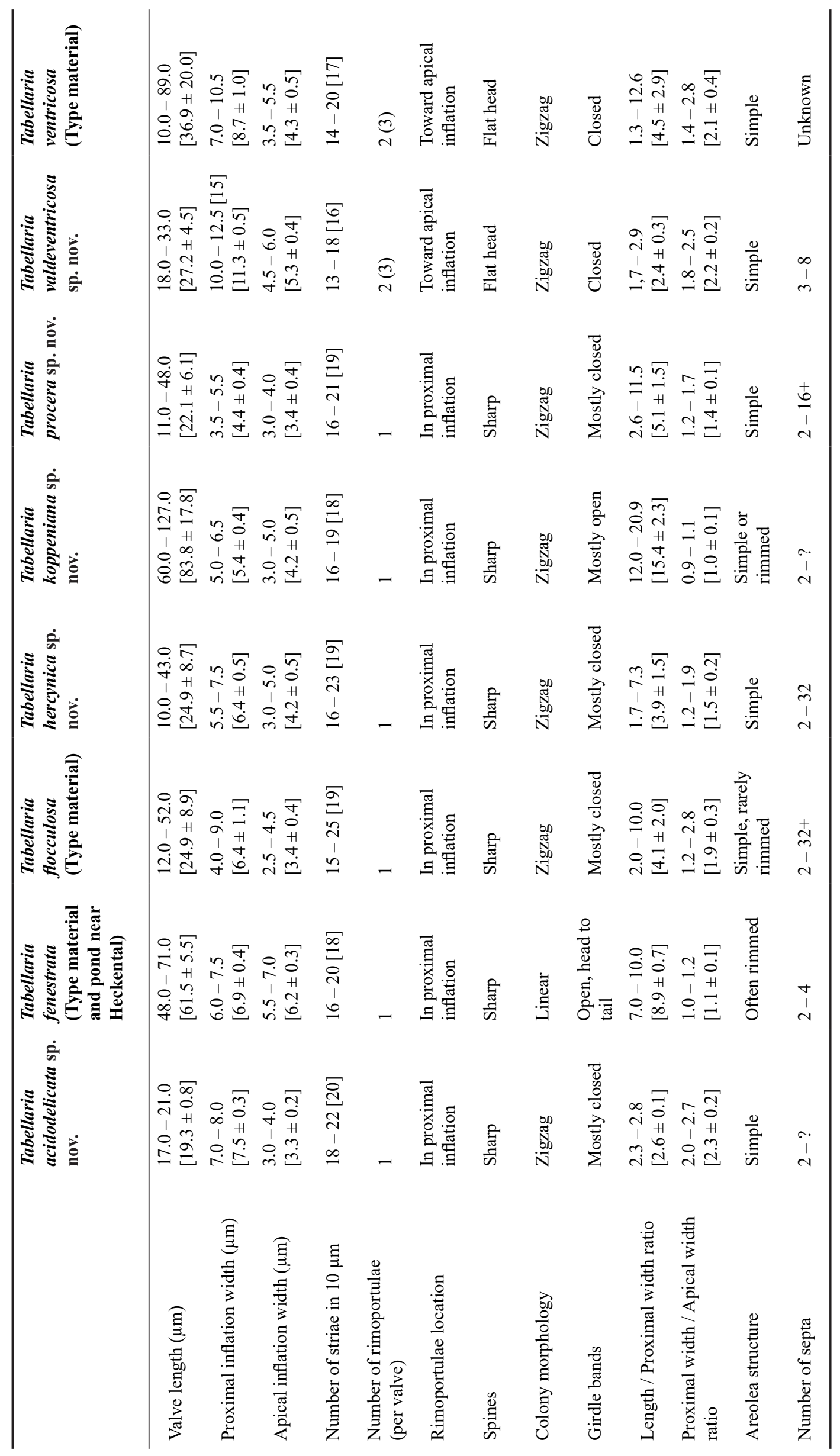


Table 3. p-values of Mann-Whitney pair test for the rectangularity descriptor (top right) and Convexity Defect Factor (bottom left). Unshaded values show significant difference between species at a one percent risk after a Bonferroni correction was applied.

\begin{tabular}{|c|c|c|c|c|c|c|c|c|}
\hline & TACD & TAPR & TFEN & TFLO & THER & TKOP & TVEN & TVVE \\
\hline TACD & & $2.07 .10^{-11}$ & $1.42 .10^{-09}$ & $1.90 .10^{-07}$ & $2.10 .10^{-09}$ & $5.56 .10^{-08}$ & $2.68 .10^{-09}$ & $3.09 .10^{-05}$ \\
\hline TAPR & $2.07 .10^{-11}$ & & $6.31 .10^{-11}$ & $4.34 .10^{-18}$ & $8.49 .10^{-10}$ & $6.56 .10^{-05}$ & $1.14 .10^{-10}$ & $1.49 .10^{-12}$ \\
\hline TFEN & $1.80 .10^{-05}$ & $2.27 .10^{-11}$ & & $7.85 .10^{-11}$ & $2.19 .10^{-01}$ & $8.66 .10^{-07}$ & $3.32 .10^{-02}$ & $1.51 .10^{-09}$ \\
\hline TFLO & $7.66 .10^{-05}$ & $4.84 .10^{-18}$ & $3.16 .10^{-01}$ & & $2.25 .10^{-11}$ & $2.29 .10^{-10}$ & $8.49 .10^{-05}$ & $1.37 .10^{-01}$ \\
\hline THER & $7.93 .10^{-09}$ & $1.72 .10^{-09}$ & $9.11 .10^{-07}$ & $1.63 .10^{-05}$ & & $4.34 .10^{-05}$ & $5.55 .10^{-03}$ & $9.43 .10^{-10}$ \\
\hline TKOP & $1.30 .10^{-07}$ & $4.56 .10^{-09}$ & $3.70 .10^{-05}$ & $1.54 .10^{-03}$ & $1.99 .10^{-01}$ & & $5.67 .10^{-06}$ & $1.75 .10^{-08}$ \\
\hline TVEN & $2.37 .10^{-09}$ & $3.83 .10^{-08}$ & $8.92 .10^{-09}$ & $1.55 .10^{-10}$ & $1.54 .10^{-02}$ & $5.45 .10^{-05}$ & & $1.02 .10^{-05}$ \\
\hline TVVE & $1.72 .10^{-03}$ & $3.26 .10^{-12}$ & $6.79 .10^{-01}$ & $8.69 .10^{-01}$ & $4.83 .10^{-04}$ & $1.95 .10^{-02}$ & $3.22 .10^{-06}$ & \\
\hline
\end{tabular}
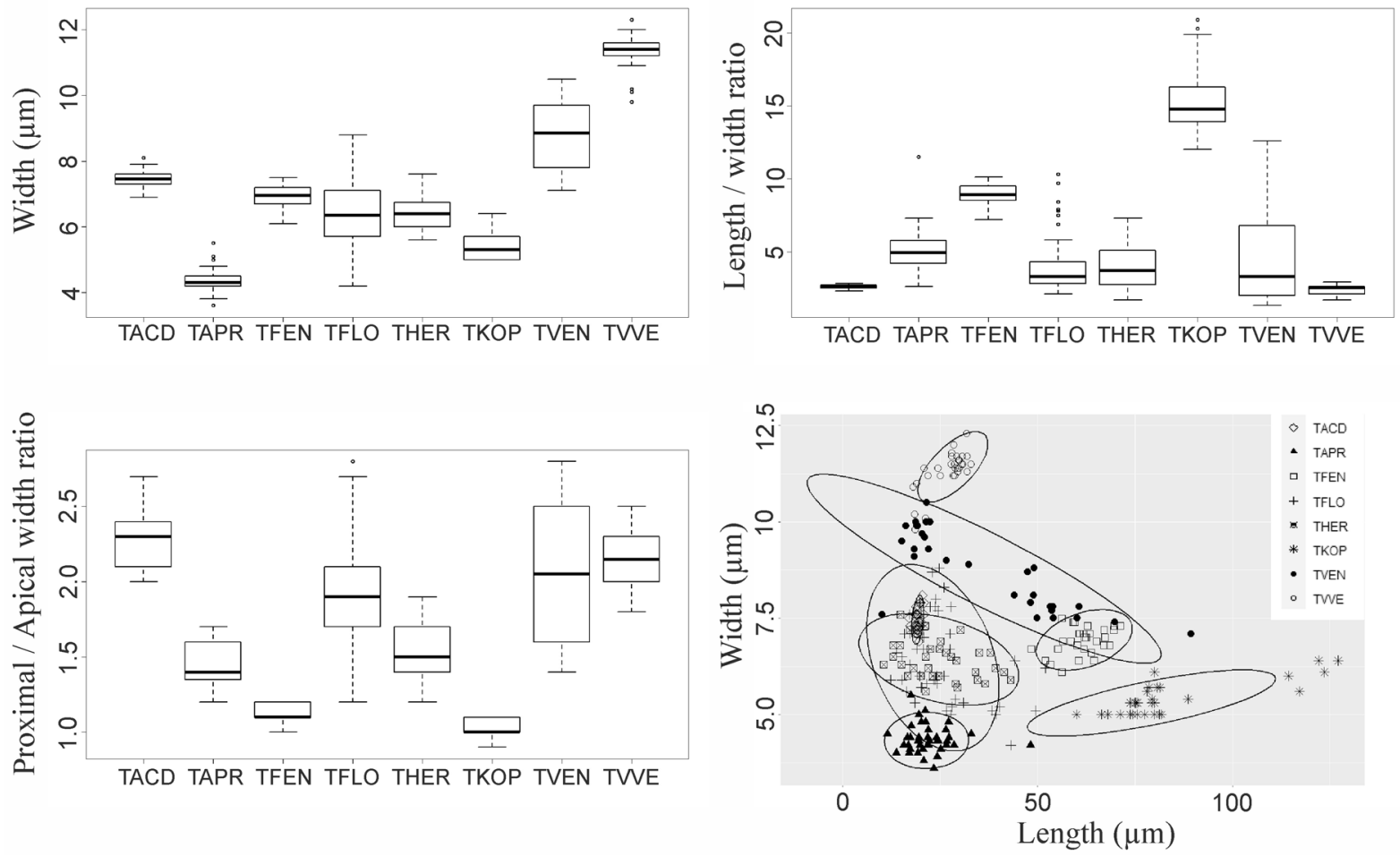

Fig. 1. Representation of the most distinctive morphometric features of the eight European Tabellaria species discussed in the present manuscript.

Morphometric data ( $=\mathbf{5 0}$; type material): length 12-52 $\mu \mathrm{m}$ (average $24.9 \pm 8.9 \mu \mathrm{m}$ ); width 4.0-9.0 $\mu \mathrm{m}$ (average $6.4 \pm 1.1 \mu \mathrm{m}$ ); stria density $15-25$ in $10 \mu \mathrm{m}$ (median 19).

Remarks: This species is known to be very variable in valve size and shape, and the observations of the valves in the neotype population confirm this statement (Figs 35-84). Hassall (1845, p. 404-406) highlighted that the valve shape changes noticeably as the size of the individuals is reduced. Our observations confirm that the typical shape of this species is well represented by the longer specimens of the type material (Figs $61,65,68-84)$ and that the shape variability increases as specimens length decreases (Figs 39-42, 46, 50) as highlighted in THERIOT \& LADEWSKI (1986). The diagnosis in KÜTZING (1844) mentioned a total length range of 6-130 $\mu \mathrm{m}$, but only a range of $12-52 \mu \mathrm{m}$ was found in the neotype designated by KNUDSON (1952). Distinctive features separating T. flocculosa from other species include the proximal inflation, generally twice as wide as the apical inflations, thin "shafts" between these inflations (1.5-3.5 $\mu \mathrm{m})$, a broad range in both length/ width ratio (2-10) and proximal width/apical width ratio (1.2-2.8), closed copulae (although also a few open ones were observed) and zigzag to star-shaped colonies observed in untreated material. This species is undoubtedly the most widespread Tabellaria species, found in both benthos and phytoplankton, ranging from unpolluted, 


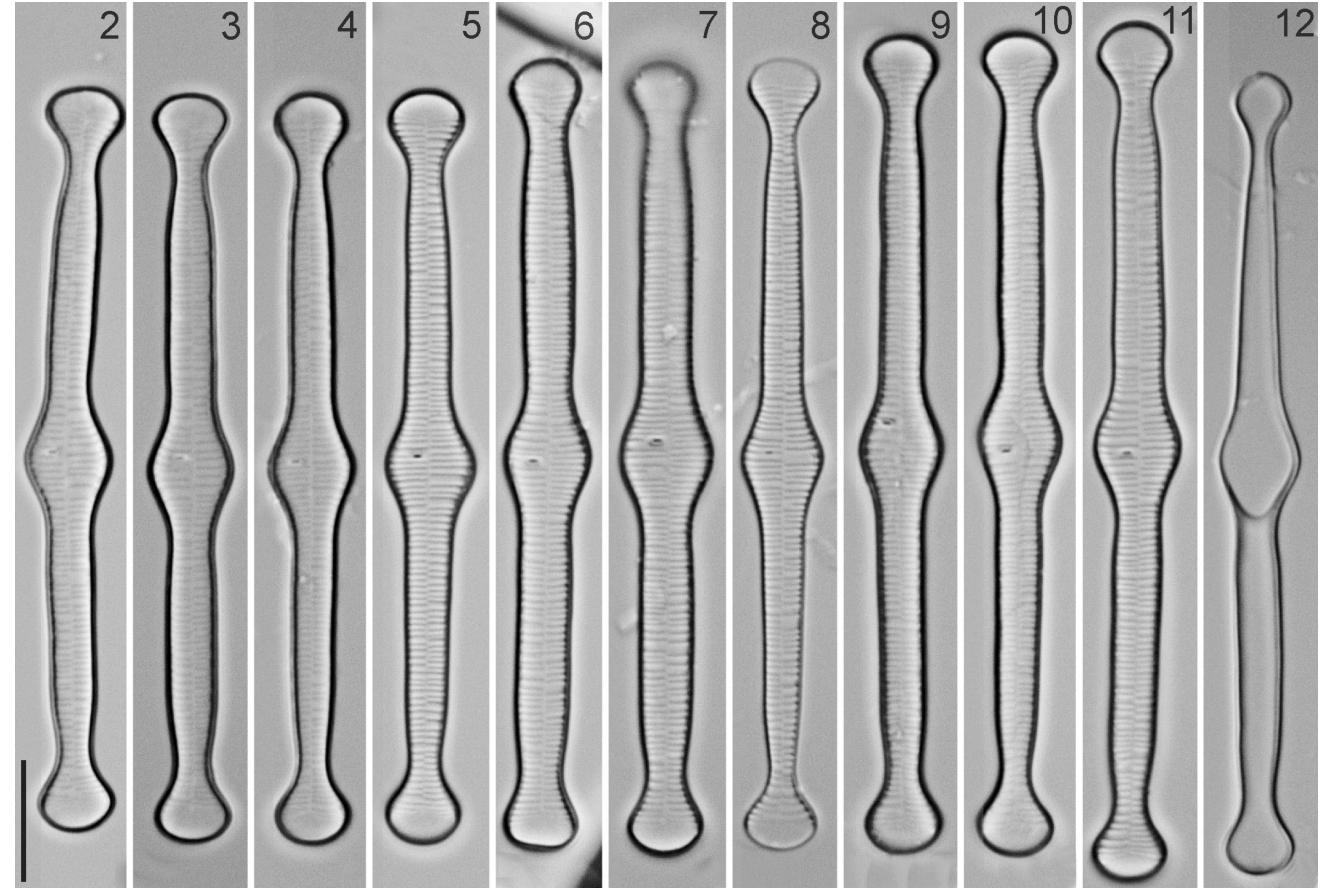

Figs 2-12. Tabellaria fenestrata (Lyngbye) Kützing, type material (Lyngbye collection, Universitets botanishke Museum, Copenhagen, Denmark): (2-11) LM valve views; (12) septa band view. Scale bar $10 \mu \mathrm{m}$.

circumneutral to slightly acidic and poorly mineralized lakes, streams and peat bogs (LANGE-BERTALOT et al. 2017). Useful information about size, variations and ecology of this species can also be found in Koppen (1975), who extensively studied North American populations.

\section{Tabellaria ventricosa Kützing (Figs 89-120)}

References: KÜTZING 1844, p. 127, pl. 30, fig. 74; non LANGE-BERTALOT 1988 , p. 418, pl. 3, figs $6,7,9-11$, pl. 4, figs $1-7$, pl. 5, figs 1,2 ; non KRAMMER \& LANGE-BERTALOT 1991, p. 109, pl. 107, figs 1-6, 10; non Hofmann et al. 2011, p. 563, pl. 3, figs 9-13; non LANGE-Bertalot et al. 2017, p. 590, pl. 4, figs 10-14.

Morphometric data $(\mathrm{n}=30$; type material): length $10-89$ $\mu \mathrm{m}$ (average $36.9 \pm 20.0 \mu \mathrm{m}$ ); width 7.0-10.5 $\mu \mathrm{m}$ (average $8.7 \pm 1.0 \mu \mathrm{m}$ ); stria density $14-20$ in $10 \mu \mathrm{m}$ (median 17). Areola density $45-50$ in $10 \mu \mathrm{m}$.

Remarks: KÜTZING (1844) validly described $T$. ventricosa as a new species based on material he most likely received from de Brébisson (Falaise, Normandy, France). Over the next 143 years this taxon was widely forgotten or only occasionally seen as a variety (e.g. Tabellaria flocculosa var. ventricosa (Kützing) Grunow) or even synonym of the catch-all taxon T. flocculosa (see VANLANDINGHAM 1978, p. 3975). LANGE-BERTALOT (1988) erected Kützing's taxon to species level based on several populations from central and northern European regions, analysing them using LM and SEM but without having observed the type material from Falaise. The question remained whether or not conspecificity between the type species and large specimens found in European samples could be assumed by means of conformity of numerical data and particularly number and position of rimoportulae as well. However, the description of a new taxon was avoided in favour of a later definitive identification of the type. The current analysis of the type material of $T$. ventricosa clearly indicated the presence of another taxon, Tabellaria valdeventricosa sp. nov., sharing two morphological features that are absent in other Tabellaria populations: (a) the presence of uncommonly inflated valve outlines and (b) the presence of two subapically placed rimoportulae, at least one on either valve. The latter is in clear contrast with other Tabellaria taxa that only possess a single, proximally situated, rimoportula. Moreover in both taxa the external rimoportula opening is circular (Figs 113, 118, 130) and comparatively very large rather than transapically slit-like prolonged as in the $T$. flocculosa species complex.

Distribution and ecology: The diatom assemblage of the type population at Falaise in Normandy is largely dominated by $T$. ventricosa (70-80\%). Two Eunotia species are worth to be mentioned, E. tenella (Grunow in Van Heurck) Hustedt in Schmidt et al. and E. juettnerae Lange-Bertalot. Particularly the first one is abundant there. The species is not confined to more strongly acidic conditions but also occurs in undisturbed, electrolyte-poor, oligo- to dystrophic habitats with higher (though still acid) $\mathrm{pH}$ levels. It is a characteristic species of low-alkalinity seepage and pool springs on siliceous substrata (CANTONATI et al. 2012). In addition to the type location at Falaise, two other habitats hosting that historical species could be found, one on the Eysturoy Island (Faeroe Archipelago) and one in Yeun Ellez (Brittany, France). The latter population was observed in a fen near the Mont-Saint-Michel on Precambrian granitic bed-rocks. The sample (collected in 1975 by LangeBertalot, unpublished results) is comparatively very species-rich. Contrary to the Falaise sample, the population 

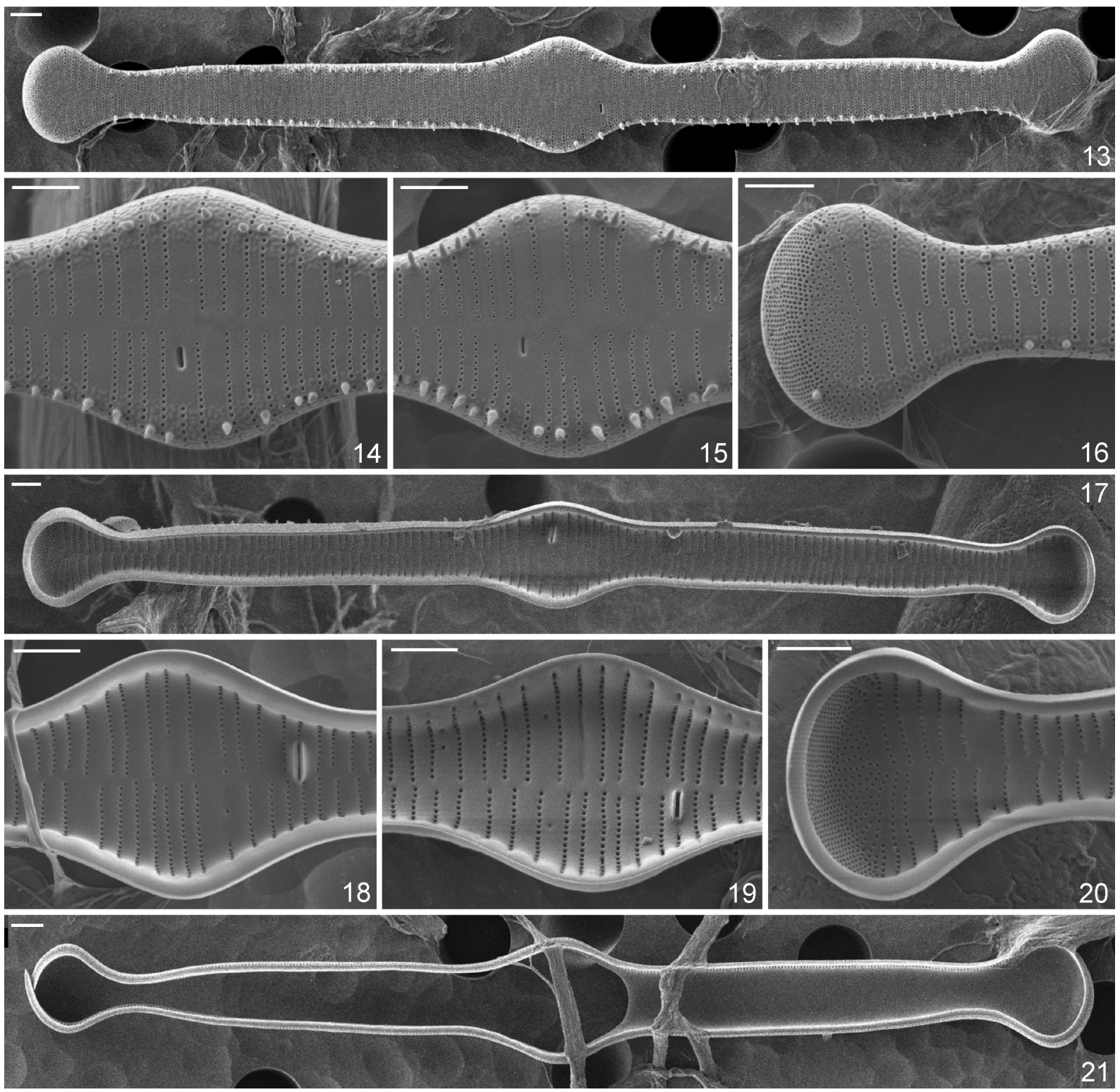

Figs 13-21. Tabellaria fenestrata (Lyngbye) Kützing, type material (Lyngbye collection, Universitets botanishke Museum, Copenhagen, Denmark): (13-21) SEM views; (13) external valve view; $(14,15)$ close up of the central inflation in external views; $(16)$ close up of apex in external view; (17) internal valve view; $(18,19)$ close up of the central inflation in external views; (20) close up of apex in external view; (21) septa band view. Scale bars $2 \mu \mathrm{m}$.

of Tabellaria ventricosa is rather small, whereas strains of T. flocculosa are much more abundant. Dominant and subdominant species respectively are Frustulia erifuga Lange-Bertalot \& Krammer, Eunotia pectinalis (Kützing) Rabenhorst, and E. soleirolii (Kützing) Rabenhorst. Remarkably, a large number of Eunotia taxa are present, though in low abundance, together with several other taxa, uncommon for a "fen assemblage" such as Cavinula cocconeiformis (W.Gregory ex Greville) D.G.Mann et Stickle, Gomphonema subclavatum (Grunow) Grunow and Meridion circulare (Greville) C.Agardh. Tabellaria ventricosa could have been overlooked or neglected in the past when present in combination of large populations of $T$. flocculosa sensu lato. The species also proved more difficult to identify in LM, especially compared to
T. valdeventricosa sp. nov., due to the small, punctiform rimoportulae, which are not so easy to observe in their sub-apical position.

\section{Description of new taxa}

Tabellaria valdeventricosa sp. nov. (Figs 121-134)

Synonym: Tabellaria ventricosa sensu LANGE-BERTALOT 1988, p. 418, pl. 3, figs 6, 7, 9-11, pl. 4, figs 1-7, pl. 5, figs 1, 2; sensu Krammer \& LANGE-Bertalot 1991, p. 109, pl. 107, figs 1-6, 10; sensu HofmanN et al. 2011, p. 563, pl. 3, figs 9-13; sensu LANGe-BerTALOt et al. 2017, p. 590 , pl. 4 , figs $10-14$.

Description: Frustules rectangular in girdle view, forming zigzag colonies (Fig. 129). 4-7 septate copulae. Valves cruciform with a rhombically inflated central part and protracted, moderately inflated apices (Figs 121-127, 130). Valve dimensions $(\mathrm{n}=30)$ : length $18-33$ 


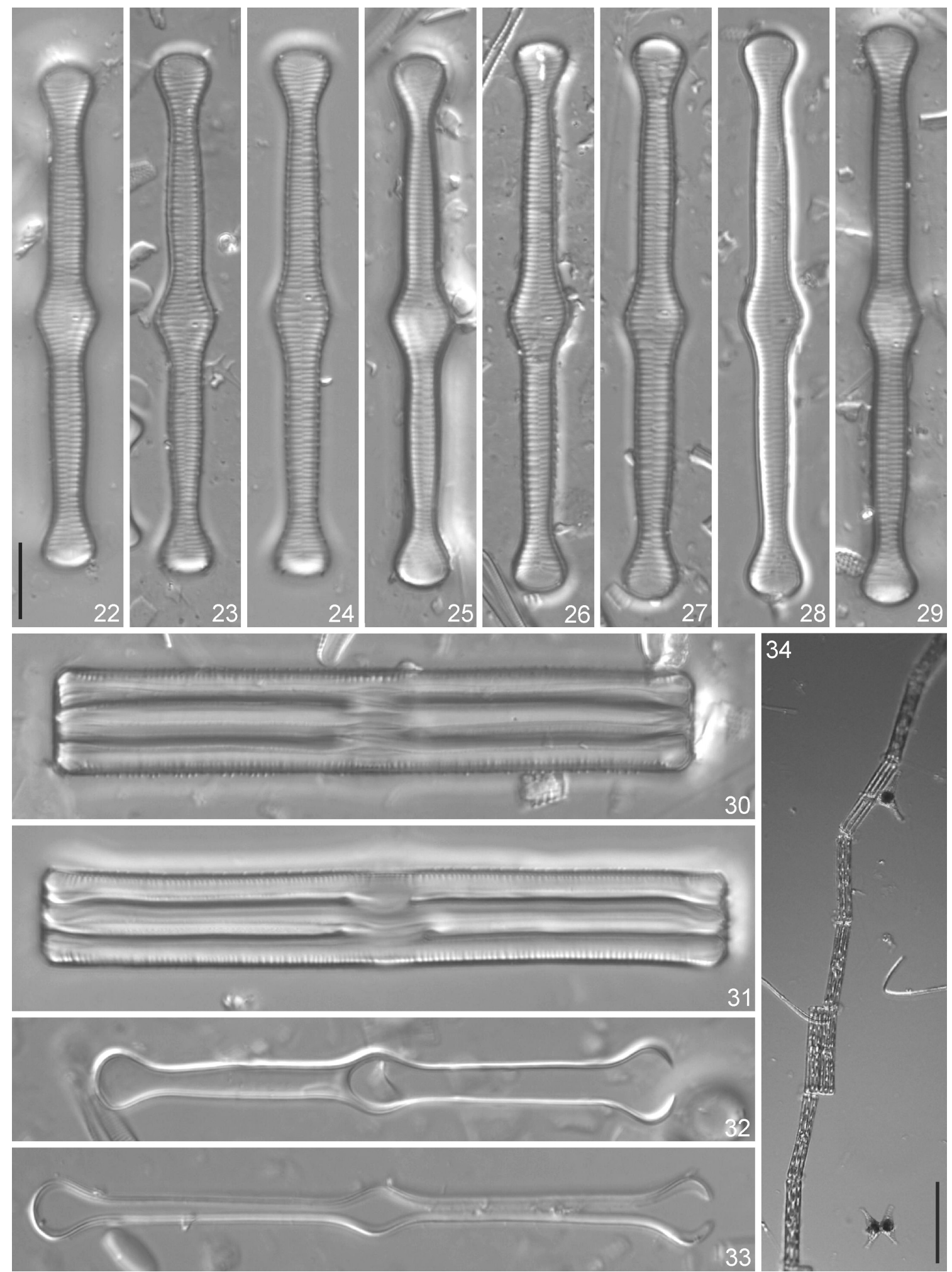

Figs 22-34. Tabellaria fenestrata (Lyngbye) Kützing, sample from unnamed pond near Heckental, Grand Est Region, France: (22-34) LM views; (22-29) valve views; $(30,31)$ girdle views; (32) septa band view; (33) non septate copula view; (34) colony in an untreated sample. Scale bars $10 \mu \mathrm{m}(2-13), 50 \mu \mathrm{m}(14)$.

$\mu \mathrm{m}$ (type population), up to ca. $40 \mu \mathrm{m}$ in one population from Germany, width (central area) 10.0-12.5 [15] $\mu \mathrm{m}$, width (apices) 4.5-6.0 $\mu \mathrm{m}$ wide, length/width ratio 1.7-2.9 (see fig 1). Striae parallel near the central area, becoming slightly radiate near the apices, $13-18$ in 10 $\mu \mathrm{m}$. Areolae $45-64$ in $10 \mu \mathrm{m}$. One or two rimoportulae present in subapical position of each pole (Figs 121-127, 130-132). External rimoportula openings circular (Fig. 130). Apical porefield composed of several regular apical rows of finer mucilage pores present at both apices (Figs 

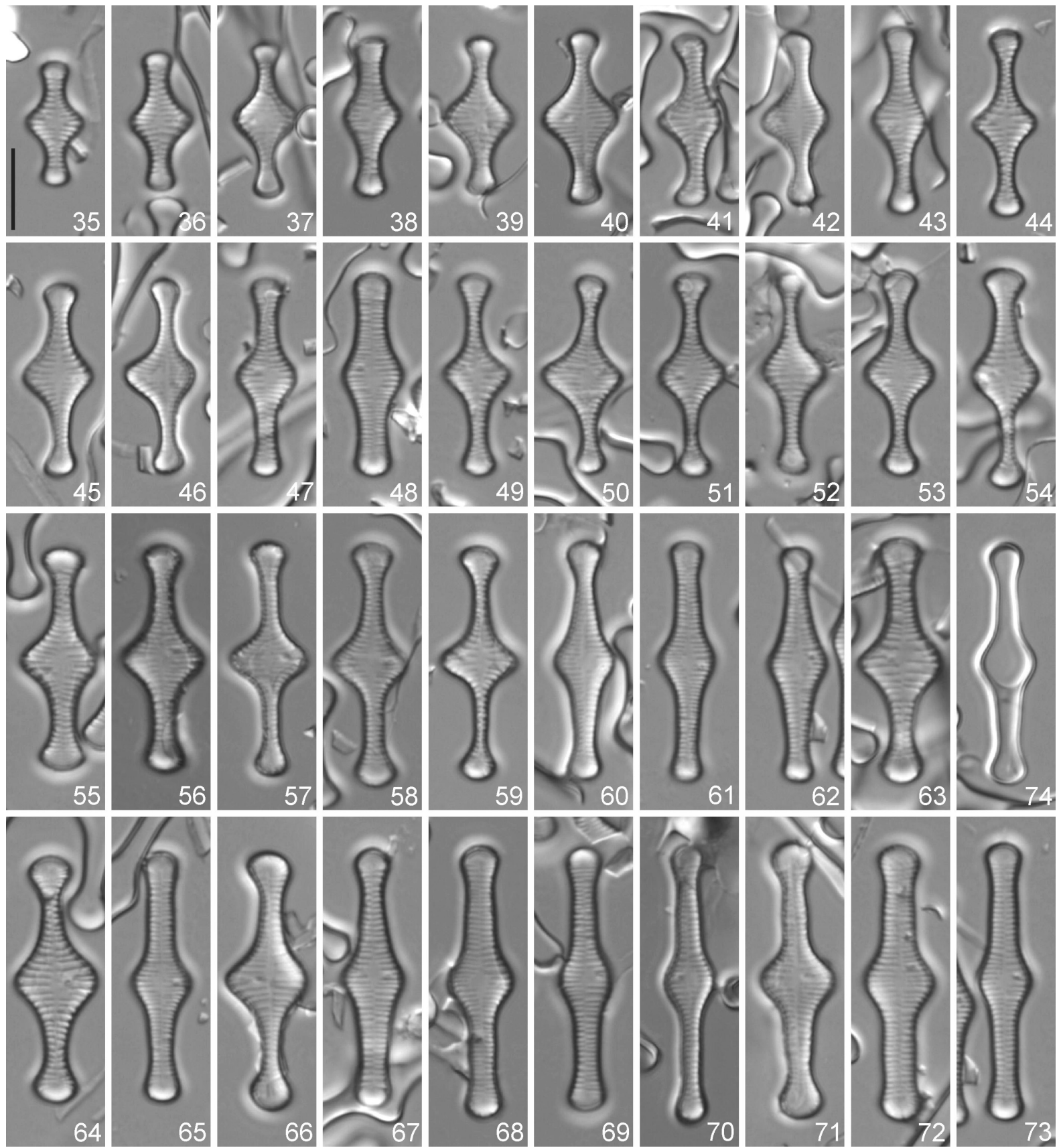

Figs 35-74. Tabellaria flocculosa (Roth) Kützing, type material (Diat. Spec. typ. No. 50 "In Aqua Dulci Naes Norvegia" from Eulenstein collection, Meise Botanic Garden, Belgium): (35-73) LM valve views; (74) LM copula view. Scale bar $10 \mu \mathrm{m}$.

130, 133). Marginal series of truncated spines present at the valve face/mantle junction (Figs 131-133).

\section{Comparison with the type population of Tabellaria} ventricosa from Falaise (Figs 89-120): Both taxa have a similar valve outline in smaller valves. Medium-sized valves of $T$. ventricosa differ by less broadly inflated proximal parts with a maximum of $10.5 \mu \mathrm{m}$. Valves with a length of 40 up to $95 \mu \mathrm{m}$ differ fundamentally since proximal widths become lower, attaining less than $9 \mu \mathrm{m}$. Similar valves have never been observed in $T$. valdeventricosa (see above under Description).

Holotype: BR-4261 (Meise Botanic Garden, Belgium), microscopic slide and preserved sample (raw material in ethanol).

Type locality: Chaufour Stream, Grange-sur-Vologne (Grand Est Region, France). (651'4"E, 486'12"N), 11 August 2018.

Distribution and ecology: Tabellaria valdeventricosa is restricted to habitats such as in springs or headwater streams (oligo- to slightly dystrophic), that are characterized by low alkalinity, low to extremely low conductivity, low $\mathrm{pH}$ values $(<5-6)$ due to acidic soils on siliceous bedrock of various geological formations. The associated diatom flora is dominated by various acidophilous taxa belonging to the genera Eunotia, Pinnularia, and 

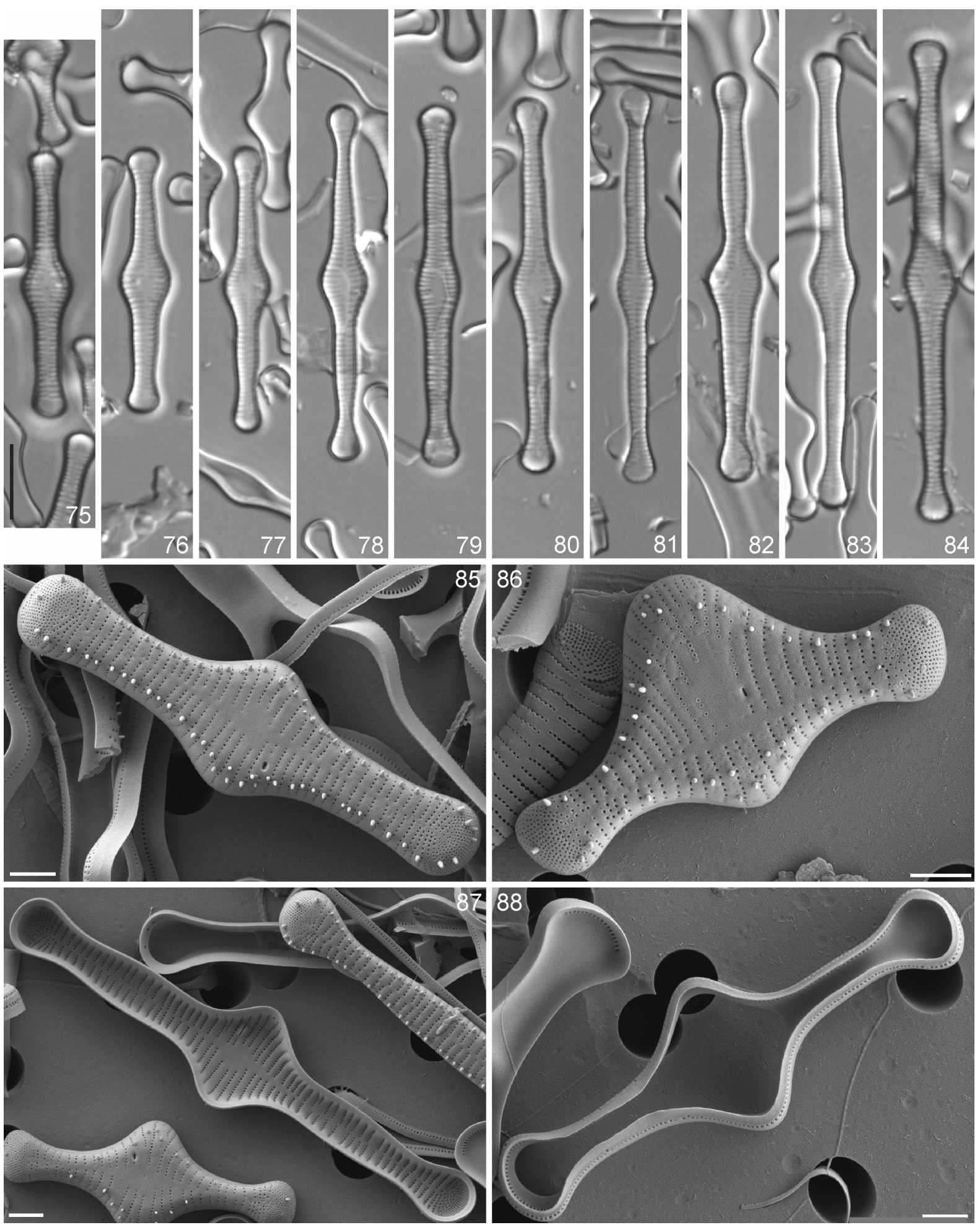

Figs 75-88. Tabellaria flocculosa (Roth) Kützing, type material (Diat. Spec. typ. No. 50 “In Aqua Dulci Naes Norvegia”. Eulenstein collection, Meise Botanic Garden, Belgium): (75-84) LM valve views; (85-88) SEM views; $(85,86)$ entire valve in external views; (87) entire valve in internal view; (88) copula view. Scale bars $10 \mu \mathrm{m}$ (LM images), $2 \mu \mathrm{m}$ (SEM images).

Brachysira. The type locality of T. valdeventricosa is a mountain stream with a low alkalinity, very low conductivity $\left(5 \mu \mathrm{S} . \mathrm{cm}^{-1}\right)$, moderately low $\mathrm{pH}(5.6)$. Accompanying taxa are typically acidophilous. Tabellaria valdeventricosa is subdominantly present and represents the only Tabellaria species in the sample. The most abundant species is Eunotia exigua. Other taxa, though in lower abundances, include Eunotia rhomboidea, E. incisa W.Gregory, E. tenella, E. juettnerae, E. trinacria Krasske, E. sudetica O.Müller, E. subarcuatoides Alles, Nörpel \& Lange-Bertalot, Frustulia erifuga, F. saxonica (morphotype II sensu LANGE-BERTALOT 

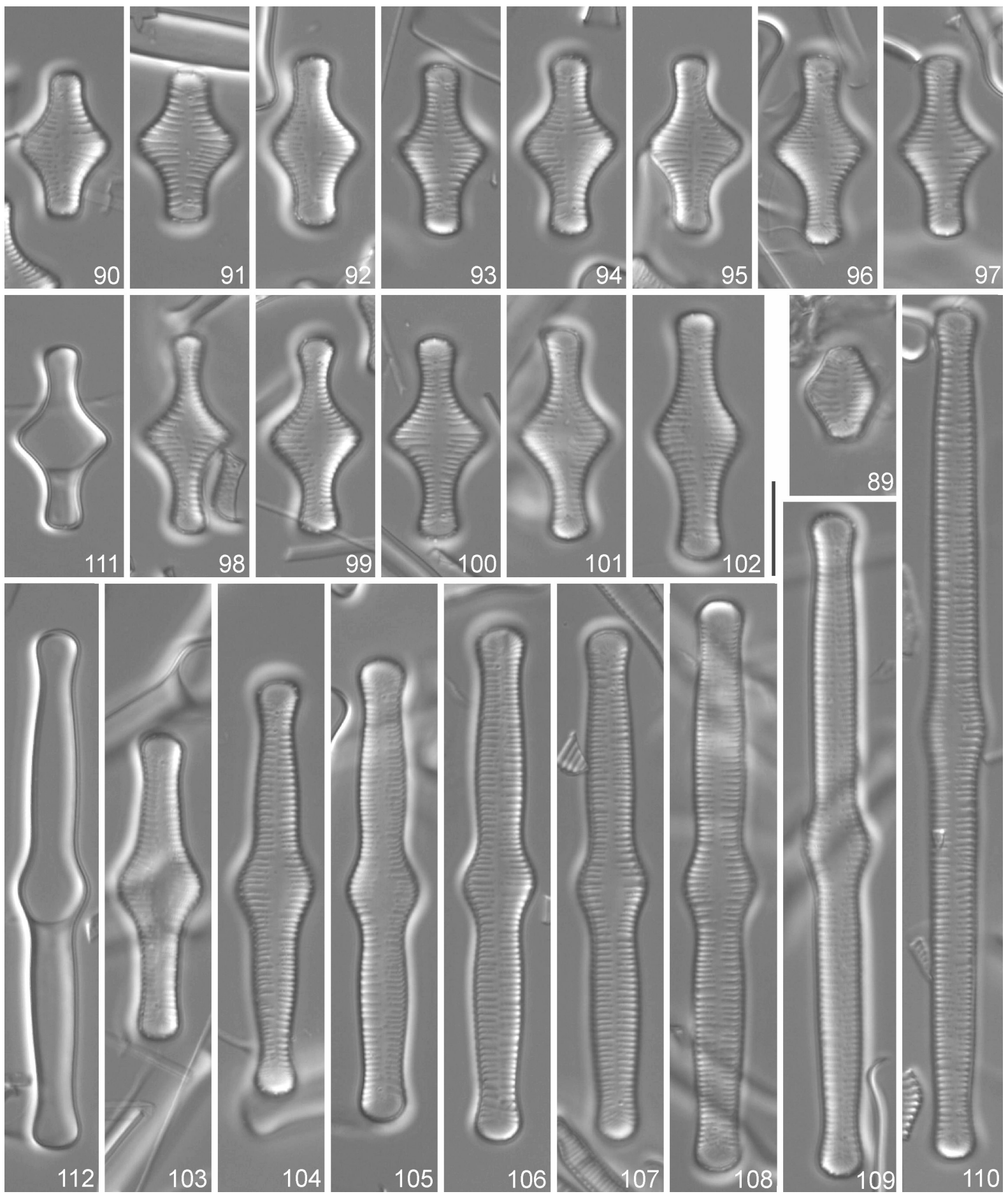

Figs 89-112. Tabellaria ventricosa Kützing, type material (sample 752 from Falaise, France. Kützing collection, Meise Botanic Garden, Belgium): (89-110) LM valve views; $(111,112)$ LM copula views. Scale bar $10 \mu \mathrm{m}$.

2001), Fragilariforma virescens (Ralfs) D.M.Williams et Round, Psammothidium subatomoides (Hustedt) Bukhtiyarova et Round and Pinnularia subcapitata W.Gregory. Another T. valdeventricosa population was observed in a minerotrophic part of a peat bog in the medium altitude Spessart Mountains on Lower Triassic red sandstone bedrocks. The sample was collected in 1979 by Lange-Bertalot (unpublished results), and has a very low $\mathrm{pH}(4.0)$ and a conductivity level below 100 $\mu \mathrm{S} . \mathrm{cm}^{-1}$. The dominant taxon in the sample is Frustulia saxonica with Brachysira serians (Brébisson) Round et D.G.Mann and Eunotia incisa being subdominant. Less abundant taxa include Tabellaria acidodelicata sp. nov., Eunotia neocompacta var. vixcompacta, E. meisterioides Lange-Bertalot. Occasionally, Eunotia exigua, E. bilunaris, E. rhomboidea, E. silvahercynia Nörpel, Van Sull et Lange-Bertalot, E. paludosa Grunow, Frustulia crassinervia (Brébisson) Lange-Bertalot et Krammer 

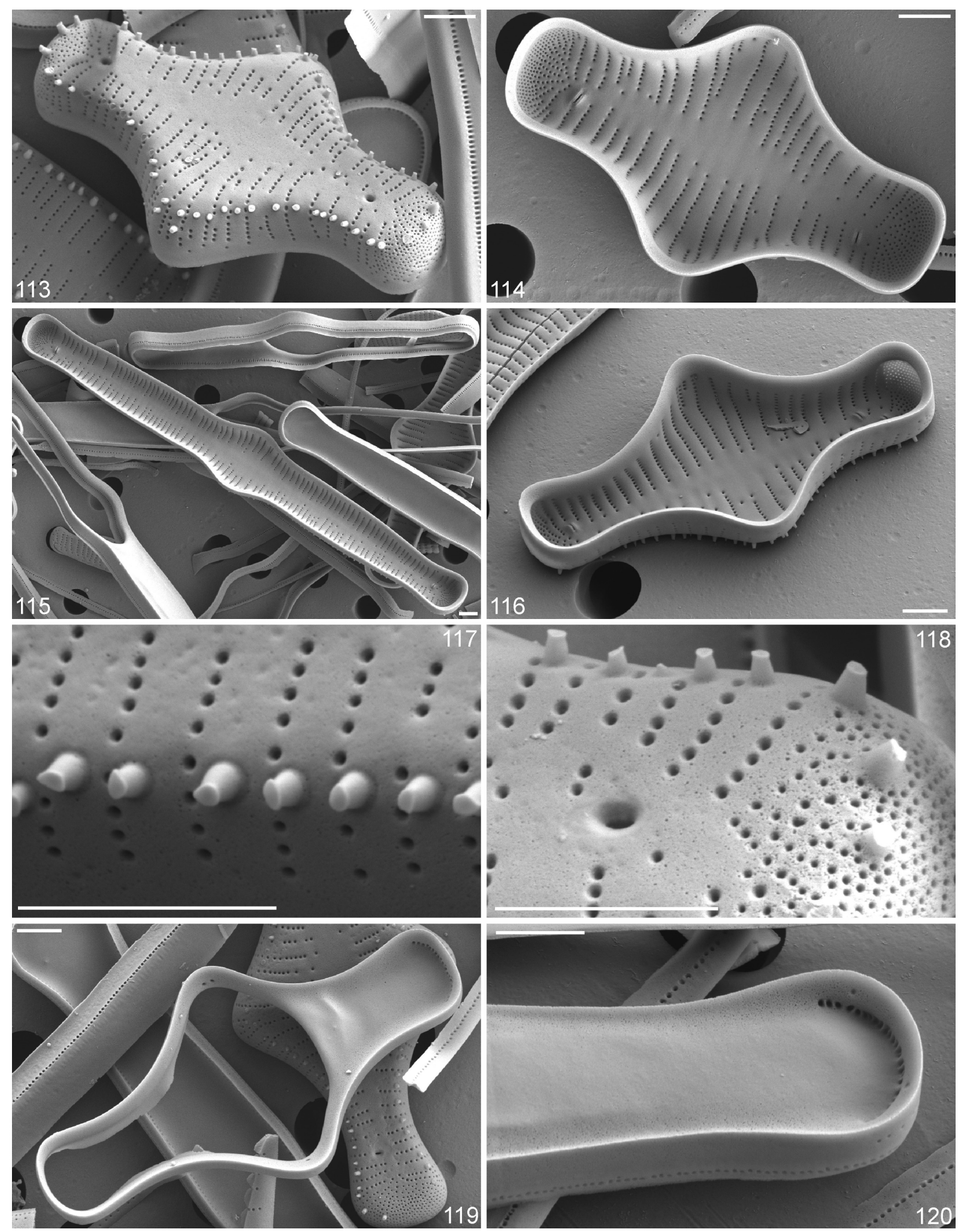

Figs 113-120. Tabellaria ventricosa Kützing, type material (sample 752 from Falaise, France. Kützing collection, Meise Botanic Garden, Belgium): (113-120) SEM views; (113) entire valve in external view; (114-116) entire valve in internal views; (117) close-up of valve face to mantle margin in external view; (118) close-up of apex in external view; (119) copula view; (120) close-up of the apex of a copula. Scale bars $2 \mu \mathrm{m}$. 

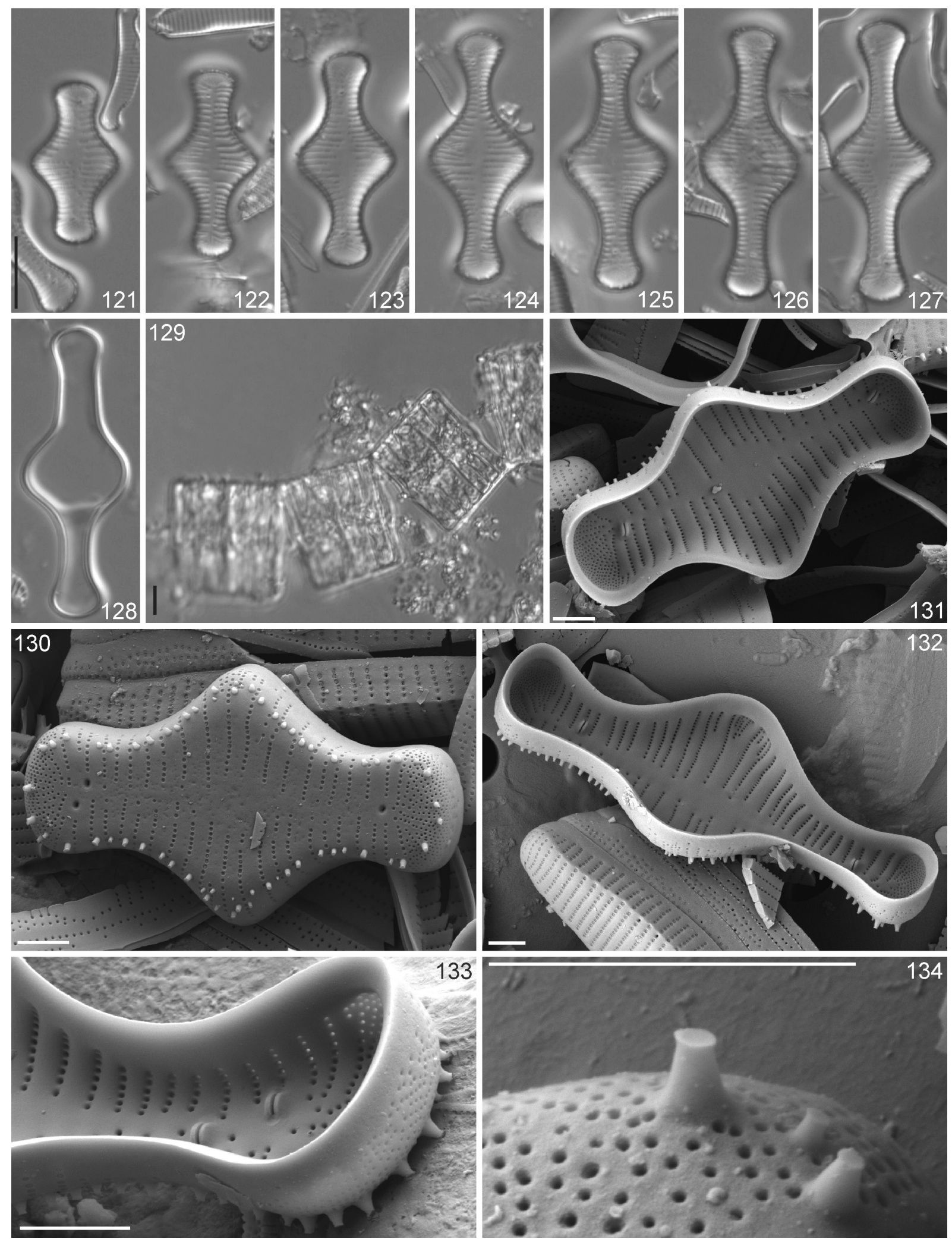

Figs 121-134. Tabellaria valdeventricosa sp. nov., type material (sample from Chaufour Stream, Grange-sur-Vologne, Grand Est Region, France): (121-127) LM valve views; (128) LM copula view; (129) LM colony in an untreated sample; (130-134) SEM views; (130) external view; $(131,132)$ internal views; (133) close up of apex in internal view; (134) close-up of spines in external view. Scale bars $10 \mu \mathrm{m}$ (LM images), $2 \mu \mathrm{m}$ (SEM images). 

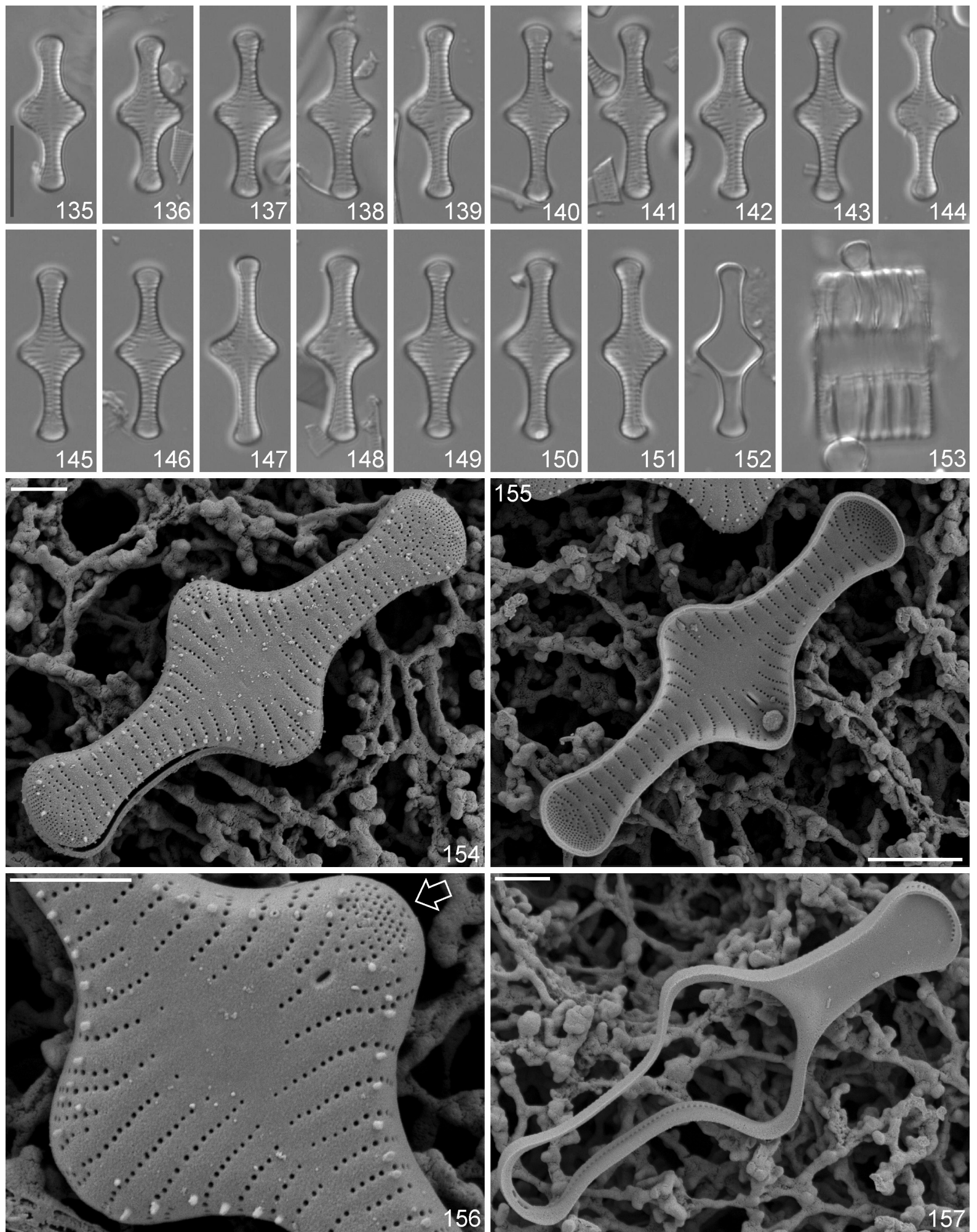

Figs 135-157. Tabellaria acidodelicata sp. nov., type material (sample from Frauenau, Germany): (135-151) LM valve views; (152) LM copula view; (153) LM girdle view; (154-157) SEM views; (154) external view; (155) internal view; (156) close up of the central inflation in external view showing the additional porefield (arrow); (157) entire copula view. Scale bars $10 \mu \mathrm{m}$ (LM images), $2 \mu \mathrm{m}$ (SEM images).

and Pinnularia gibbiformis Krammer are observed but always in low abundance.

Tabellaria acidodelicata sp. nov. (Figs 135-157)

Description: Frustules rectangular in girdle view (Fig.
153). Number of copulae indefinite, many. Smaller stages of the valve diminution series hard to distinguish from $T$. flocculosa. Valve outline cruciform with large central and terminal inflations (Figs 135-151, 154). Valve dimensions $(\mathrm{n}=30)$ : valve length $17.0-21.0 \mu \mathrm{m}$, 

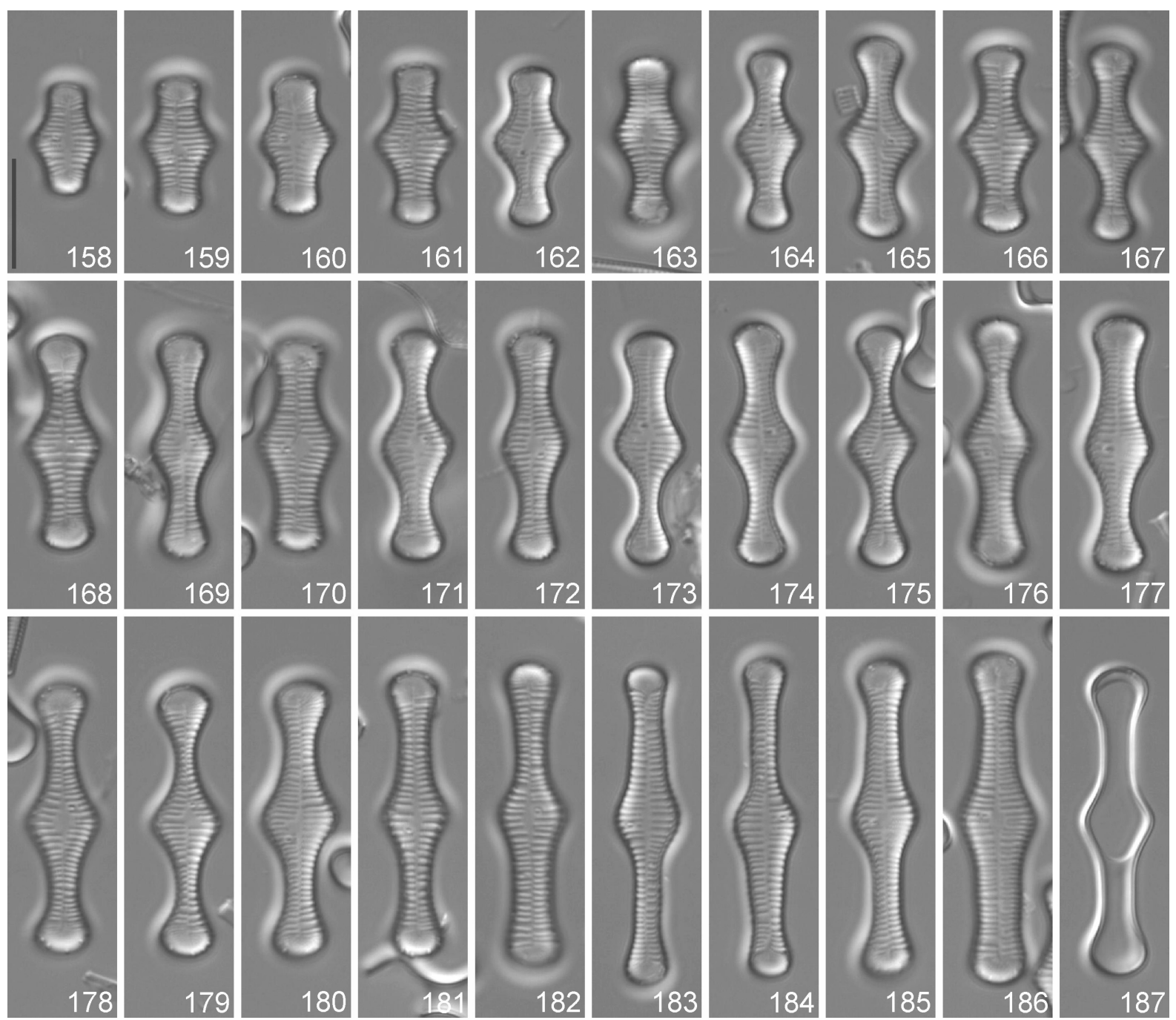

Figs 158-187. Tabellaria hercynica sp. nov., type material (from Gérardmer Lake, Gérardmer, Grand Est Region, France): (158-186) LM valve views; (187) LM copula view. Scale bar $10 \mu \mathrm{m}$.

width (central part) 7.0-8.0 $\mu \mathrm{m}$, width (apices) 3-4 $\mu \mathrm{m}$. Length/width ratio $2.3-2.8$. Central inflation usually strictly rhombical, much larger than the subcapitate to distinctly capitate ends. Axial area very narrow, less than $0.5 \mu \mathrm{m}$ wide. Central area clearly set off, rhombical or variable in shape, extended to $1 / 3-1 / 2$ of the total valve width. Striae radiate throughout, $18-22$ in $10 \mu \mathrm{m}$, usually alternating. Areolae 55-60 in $10 \mu \mathrm{m}$. One single rimoportula opening integrated in one of the proximal striae, more or less transapically elongated (Figs 154-156). Large apical porefields present on both apices (Fig. 154). Small additional porefield occasionally present on one side of the central inflation (Fig. 156). Marginal row of small spines present with spines usually positioned on the virgae (Figs 154, 156).

Other populations of this taxon: In the same region (Bavarian Forest Mountains as integrated western part of the Bohemian Massif) where T. acidodelicata and T. valdeventricosa occur associated, likewise in large numbers, the first one is uniformly $20-25 \mu \mathrm{m}$ long and consistently about 7-8 $\mu \mathrm{m}$ wide. Specimens photographed by LANGe-Bertalot (1988, pl. 3, figs 8-11, associated with $T$. valdeventricosa, erroneously identified as Tabellaria flocculosa strain IV sensu KopPEN) belong actually to T. acidodelicata sp. nov. They originate from acid mountain streams with extremely low conductivity due to lower Devonian or Lower Triassic sandstones respectively in central Germany. CAMBURN \& CHARLES (2000, pl. 10, figs 8-13) record obviously a conforming population from "Low Alkalinity" lakes in the Adirondack Park, northeastern U.S.A.: the documented specimens are 20-27 $\mu \mathrm{m}$ long, 6-8 $\mu \mathrm{m}$ wide and possess likewise 18-20 striae in $10 \mu \mathrm{m}$. The valve depicted on fig. 13 has a length of $27 \mu \mathrm{m}$ and most likely represents a stage close to a post-primary cell. On the other hand, strain IV of T. flocculosa in the original sense of KOPPEN (1975, figs $9,10,16 \mathrm{~A}, 23-26,32)$ is $15-39 \mu \mathrm{m}$ long, $7.5-8.5$ $\mu \mathrm{m}$ wide, possessing $14-16$ striae in $10 \mu \mathrm{m}$, is clearly distinguished and certainly not conspecific with all aforementioned populations.

Comparison with the Tabellaria flocculosa type population (Naes Norvegiae) (Figs 35-88): Based on 

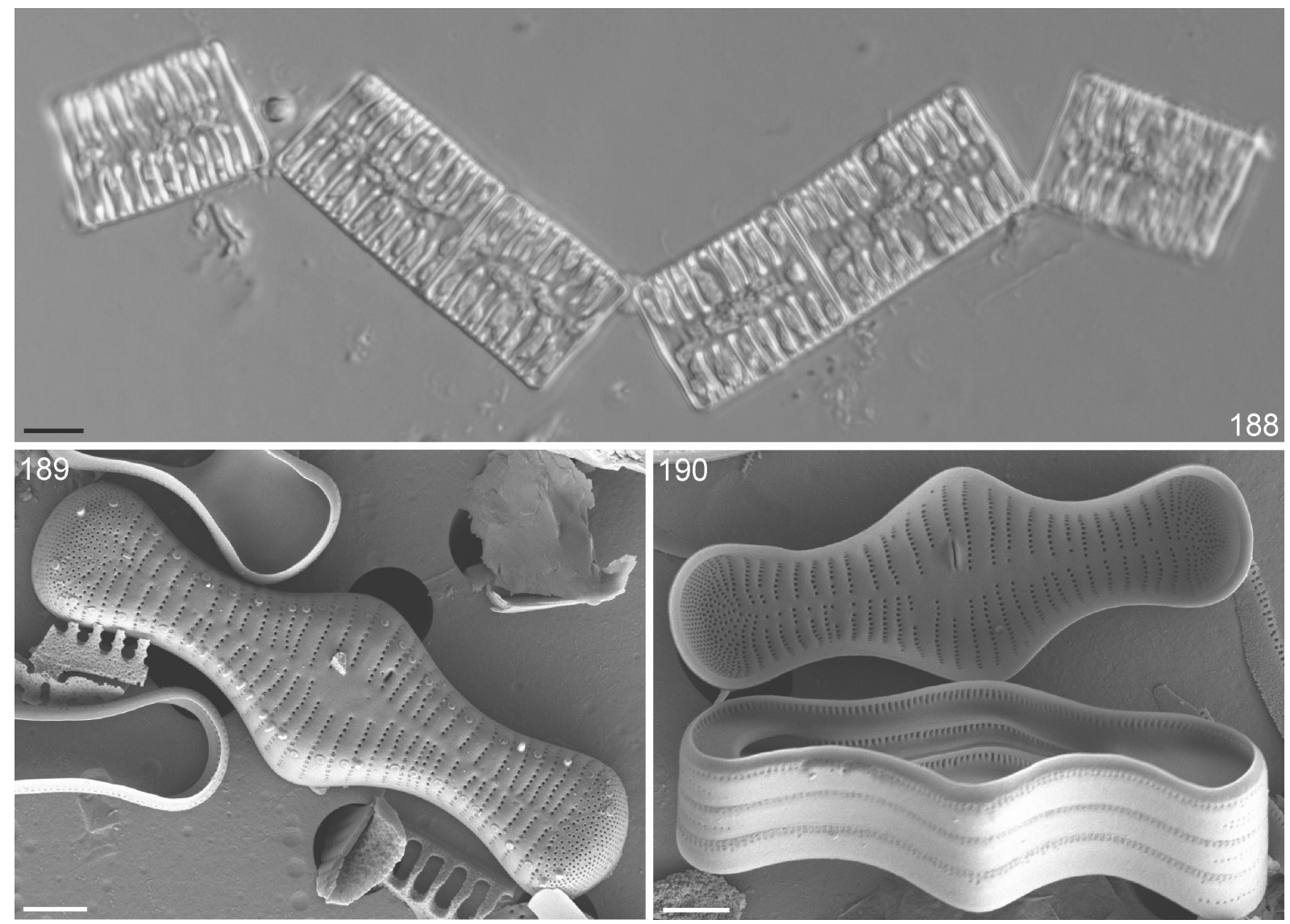

Figs 188-190. Tabellaria hercynica sp. nov., type material (sample from Gérardmer Lake, Gérardmer, Grand Est Region, France): (188) LM colony view on untreated sample; (189) external SEM view; (190) internal SEM view on three linked copulae below. Scale bars $10 \mu \mathrm{m}$ (LM images), $2 \mu \mathrm{m}$ (SEM images).

observations of the type and other conforming populations of Tabellaria flocculosa, a maximum valve length of 65 $\mu \mathrm{m}$ (and perhaps slightly more) was noted with a length/ width ratio of up to 10 (vs. 2.3-2.8 in T. acidodelicata). Such long valves have never been observed among many thousands of specimens in more than hundred samples from European low alkalinity waters containing T. valdeventricosa associated with $T$. acidodelicata. Medium-sized stages of T. flocculosa, i.e. the only ones actually resembling $T$. acidodelicata in outline and length/width ratio, may prove difficult to separate if observed alone as they differ only by a broader range in stria density (15-25 in $10 \mu \mathrm{m}$ vs. 18-22 in $10 \mu \mathrm{m}$ for T. acidodelicata). However, T. flocculosa has different ecological preferences and almost always had longer individuals in observed populations. The areola density of $T$. flocculosa type specimens is $45-50$ in $10 \mu \mathrm{m}$ (vs. about 60 in the type population of T. acidodelicata). However, the areola density of other T. acidodelicata populations outside Europe is inconsistent, which makes this feature useless to separate both taxa.

Holotype: Box "Danube / Donau with tributaries" slide no. 50 (prep. Dr Gabriele Hofmann) in Collection Lange-Bertalot (FR).

Isotype: BR-4622 (Meise Botanic Garden, Belgium), microscopic slide and preserved sample (raw material in ethanol).

Type locality: Creek "Kleiner Rachelbach", Frauenau, Germany (12²3'17"E, 48 59'35"N), 02 November 2004. Etymology: The species name is based on the Latin adjectives acidus ('acid') and delicatus ('delicate'), pointing to the habitat ecology including low $\mathrm{pH}$ in combination with its graceful appearance compared to other Tabellaria taxa.

Distribution and ecology: The type locality, situated on granite and gneiss bedrock, has been included in a long-time water quality assessment. The $\mathrm{pH}$ is permanently below 5 and its conductivity varies between $20-43$ $\mu \mathrm{S} . \mathrm{cm}^{-1}$. Dominating taxa of the diatom assemblage are T. acidodelicata (42\%) and T. valdeventricosa (36\%), associated with high individual numbers of Eunotia exigua (Brébisson ex Kützing) Rabenhorst, E. incisa, E. rhomboidea Hustedt, and E. tenella. Other, less frequent, taxa include Psammothidium acidoclinatum (Lange-Bertalot) Lange-Bertalot, Frustulia saxonica Rabenhorst, Pinnularia subcapitata, Eunotia cf. mucophila (Lange-Bertalot et Nörpel-Schempp) LangeBertalot in Metzeltin et Lange-Bertalot, E. sudetica, E. neocompacta var. vixcompacta Lange-Bertalot in Lange-Bertalot, Bąk et Witkowski and E. ursamaioris Lange-Bertalot et Nörpel-Schempp in Lange-Bertalot et Genkal. Eunotia exigua and other acidophilous taxa 


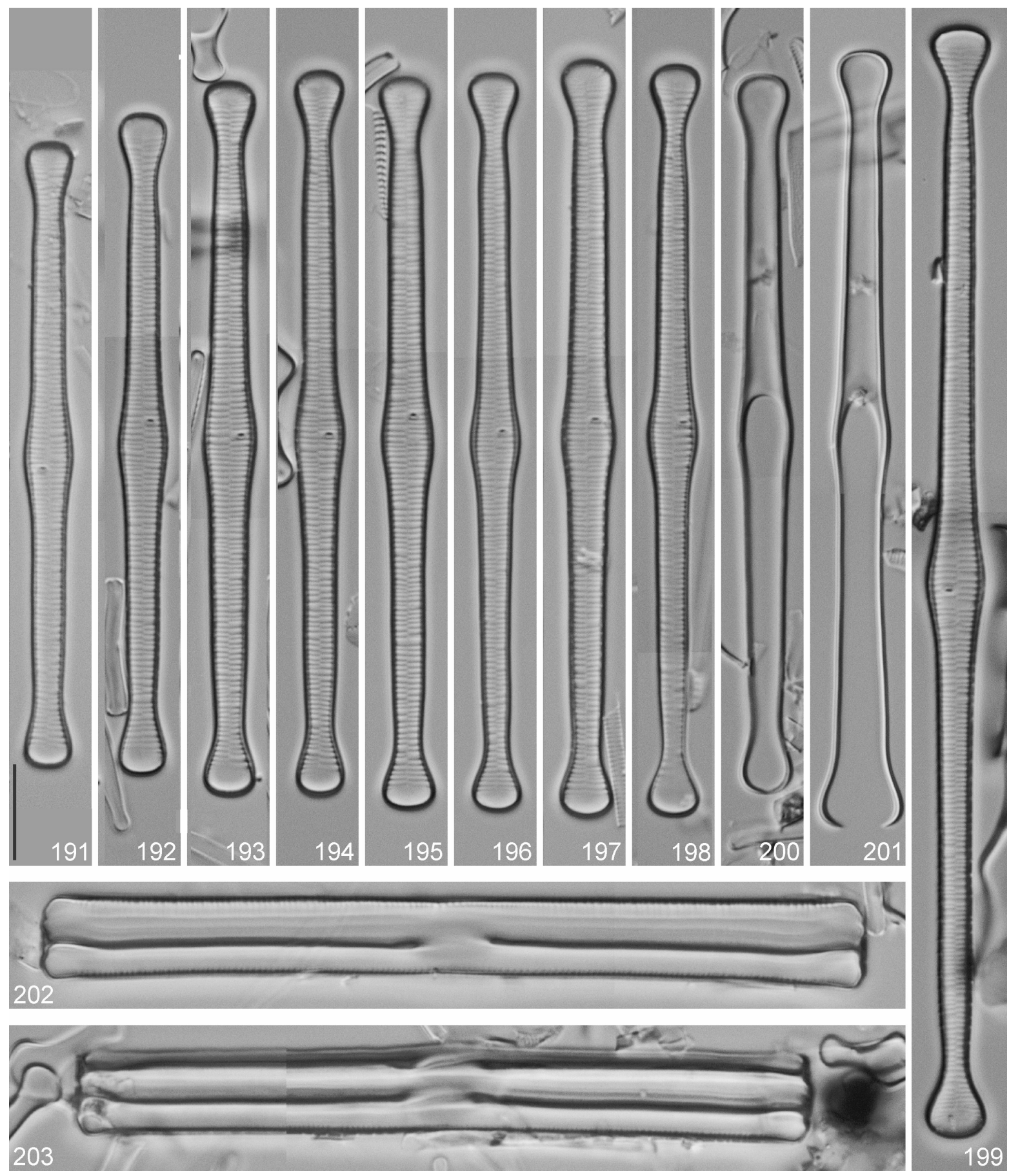

Figs 191-203. Tabellaria koppeniana sp. nov., type material (sample from Rattån, Sweden): (191-199) LM valve views; (200, 201) LM copula views; $(202,203)$ LM girdle views. Scale bar $10 \mu \mathrm{m}$.

can be observed associated with T. acidodelicata and $T$. valdeventricosa and considered typical for such habitats. The composition and abundance of associates varies between all samples collected in more than hundred European locations.

Tabellaria hercynica sp. nov. (Figs 158-190)

Description: Frustules in girdle view rectangular (Fig. 188), hard to distinguish from the type of T. flocculosa. Valves weakly cruciform with a weakly inflated, rhombical central part throughout the entire valve diminution series (Figs 158-186). Apices weakly protracted, broadly rounded (Figs 158-163). Valve dimensions $(n=35)$ : valve length $10.0-43.0 \mu \mathrm{m}$, width (central part 5.5-7.5 $\mu \mathrm{m}$ ), width (apices) 3-5 $\mu \mathrm{m}$, length/width ratio 1.7-7.3. Axial area very narrow, distinctly less than $0.5 \mu \mathrm{m}$ wide. Central area irregularly widened, $1.5-2 \mu \mathrm{m}$ wide. One single rimoportula visible, located at the end of a stria, close to the axial area, slightly eccentrical, appearing moderately transapically elongated (Figs 178, 189). Striae radiate throughout, moderately more radiate near the apices with a few striae in subdistal position, 16-23 in $10 \mu \mathrm{m}$. Striae 

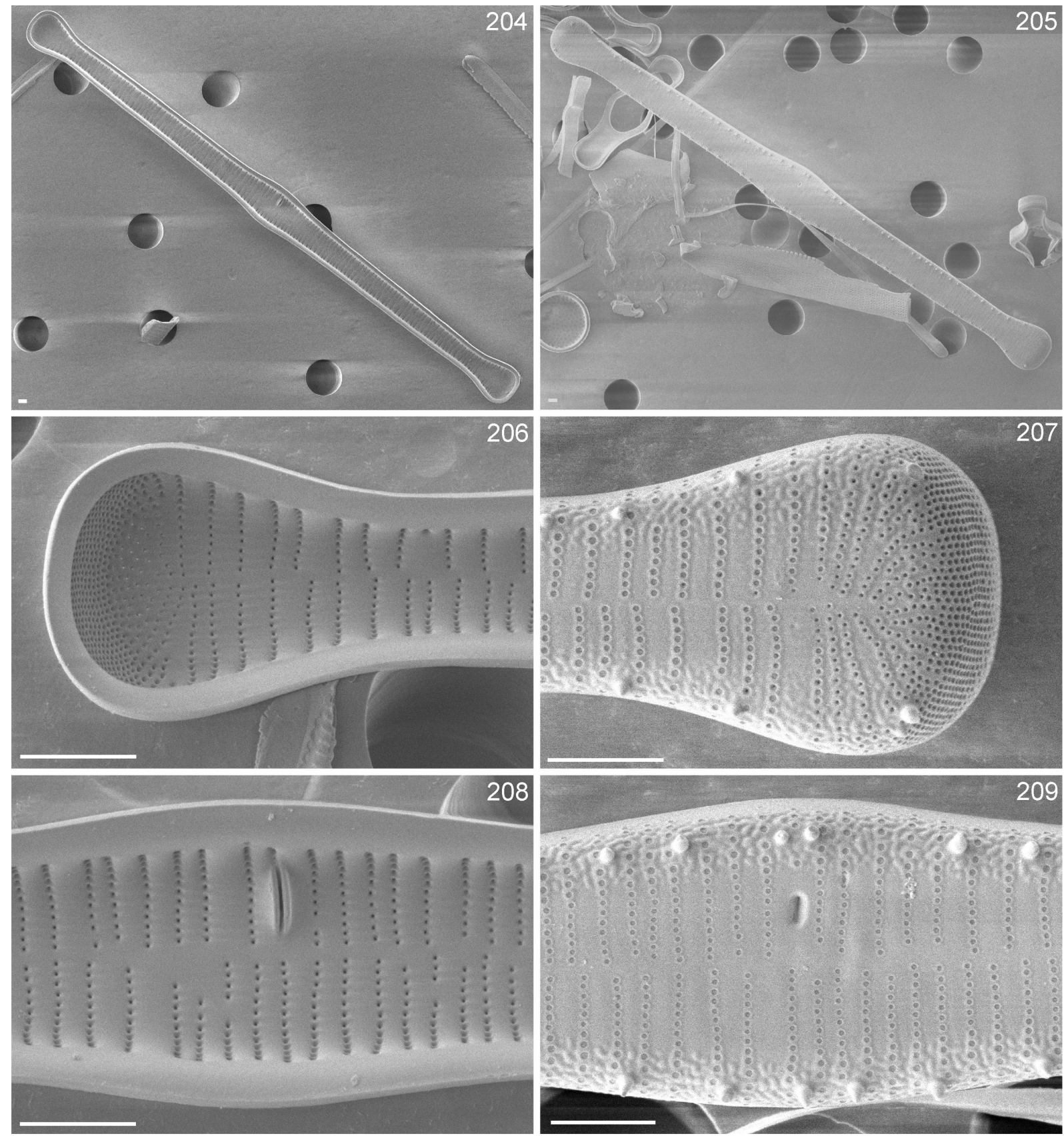

Figs 204-209. Tabellaria koppeniana sp. nov., type material (sample from Rattån, Sweden): (204-209) SEM views; (204) entire valve internal view; (205) entire valve external view; (206) close up of apex in internal view; (207) close up of apex in external view; (208) close up of central inflation in internal view; (209) close up of central inflation in external view. Scale bars $2 \mu \mathrm{m}$.

in SEM somewhat irregularly spaced, pairs from either side mostly in opposed position, some alternating (Fig. 173). Areolae indiscernible in LM, about 50 in $10 \mu \mathrm{m}$. Apical porefield composed of many regular apical rows of finer mucilage pores present at both apices. Marginal row of small spines present, inserted on virgae. Internally, rimoportula slit-like with two raised rims. Copulae closed with one all around row of elongated perforations and several extra rows of pores at the apices.

Comparison with the Tabellaria flocculosa type population (Naes Norvegiae) and T. fenestrata (see also Fig. 1): Tabellaria hercynica can be separated from T. flocculosa by the smaller difference in width between the central inflation and the apices, and the broader connecting sections between the central part and the apices, throughout the entire valve diminution series. Those features are more distinct when considering mean values based on measurements of multiple specimens and not isolated individuals (Fig. 1). This also induces distinctive valve outlines for the two species (Figs 35-84, 158-186). The capitate apices of T. hercynica have a width of 3.0-5.0 $\mu \mathrm{m}$ vs. $2.5-4.5 \mu \mathrm{m}$ in the other species. Even if it does not prove to be useful as a separating feature, the central inflation is not significantly wider but is less variable 


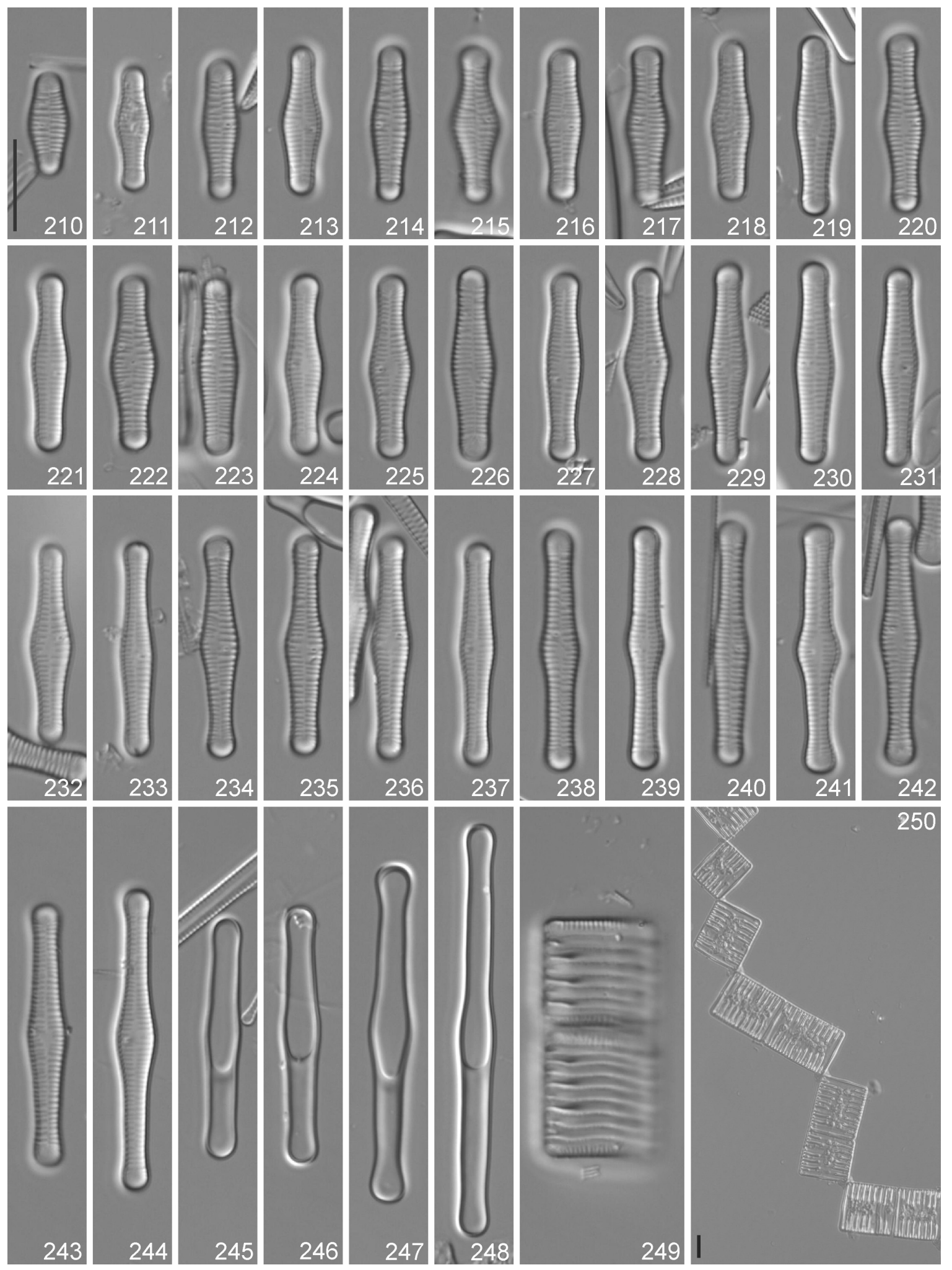

Figs 210-250. Tabellaria procera sp. nov., type material (sample from Cazaux Lake, La Teste-de-Buch, Nouvelle Aquitaine Region, France) : (210-244) LM valve views; (245-248) LM copula views; (249) LM girdle view; (250) LM colony in untreated sample. Scale bar $10 \mu$ m.

in size with 5.5-7.5 (vs. 4.0-9.0) $\mu \mathrm{m}$. The connecting sections in between central part and apices are 2.5-4 $\mu \mathrm{m}$ wide vs. $1.5-3.5 \mu \mathrm{m}$ in the other species. In mixed (associated) populations as critically observed from the Vosges and Black Forest Mountains, the separation of smaller to medium-sized valves is rather straightforward. The different appearance in LM view and numerical data have obviously been neglected in the past. For instance the specimens in LANGE-Bertalot (1988, pl. 1, fig. 13) and Heudre et al. (2018, fig. 10) have most likely 

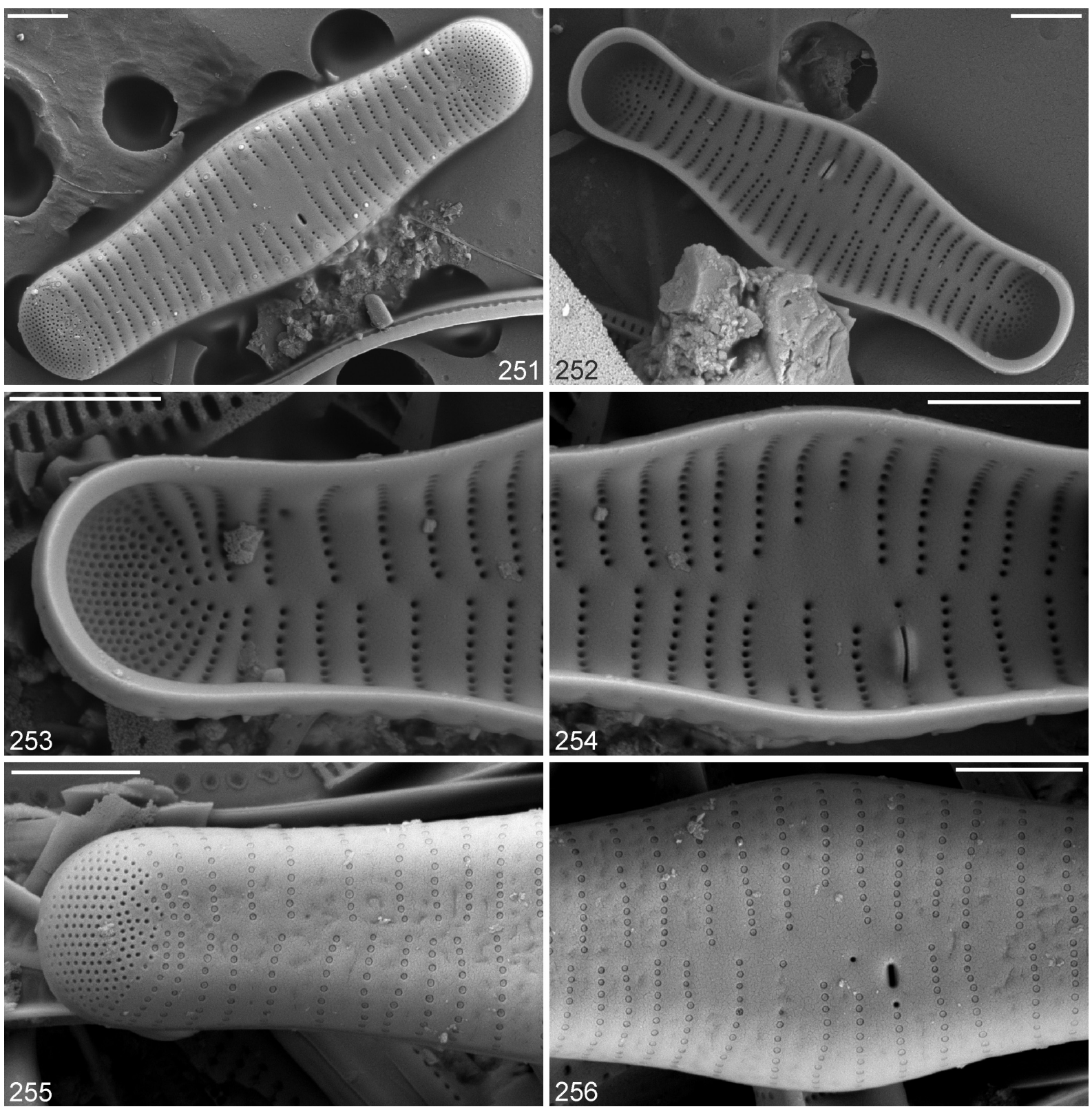

Figs 251-256. Tabellaria procera sp. nov., type material (from Cazaux Lake, La Teste-de-Buch, Nouvelle Aquitaine Region, France) : (251256) SEM views; (251) external view; (252) internal view; (253) close-up of apex in internal view; (254) close-up of proximal part in internal view; (255) close-up of apex in external view; (256) close-up of proximal part in external view. Scale bars $2 \mu \mathrm{m}$.

been misidentified as T. flocculosa. Similarly, the valve outline of $T$. hercynica resembles $T$. fenestrata, but the separation of both taxa can be done based on other morphological features such as in particular the lower width of the apices (3.0-5.0 vs. 5.5-7.0 $\mu \mathrm{m})$, the lower length/ width ratio (1.7-7.3 vs. $7.0-10)$, the number of septa in girdle views (2-32 vs 2-4), as well as morphology of colonies on raw material (Figs 34, 188).

Holotype: BR-4623 (Meise Botanic Garden, Belgium) represented by Fig. 180, microscopic slide and preserved sample (raw material in ethanol).

Type locality: Gérardmer Lake, Gérardmer (Grand Est Region, France) (6 $6^{\circ} 1^{\prime} 12^{\prime \prime E}, 48^{\circ} 4^{\prime} 1$ 'N), 19 August 2015. Etymology: The specific epithet 'hercynica' refers to the Latin name of the septentrional European (in line of sight from Roma to the North) medium altitude forest-covered mountains extending between the Rhine and the Carpathians: "silvahercynia".

Distribution and ecology: As yet only two populations have been investigated and compared to the type population of $T$. flocculosa in Norway. The type locality of $T$. hercynica is Gérardmer Lake in the Vosges Mountains, eastern France (Grand Est Region). The following environmental values were measured on 19 August 2015 from Gérardmer Lake (type): water temperature $19.2^{\circ} \mathrm{C}$, $\mathrm{pH} 7.7$, conductivity $91 \mu \mathrm{S} . \mathrm{cm}^{-1}$, dissolved oxygen 9.0 mg. $1^{-1}$, dissolved oxygen saturation $105 \%$. See Heudre et al. (2018) for a description of the lake, detailed physicochemical data and its diatom assemblage. The second population originates from the Feldsee, a minerotrophic 

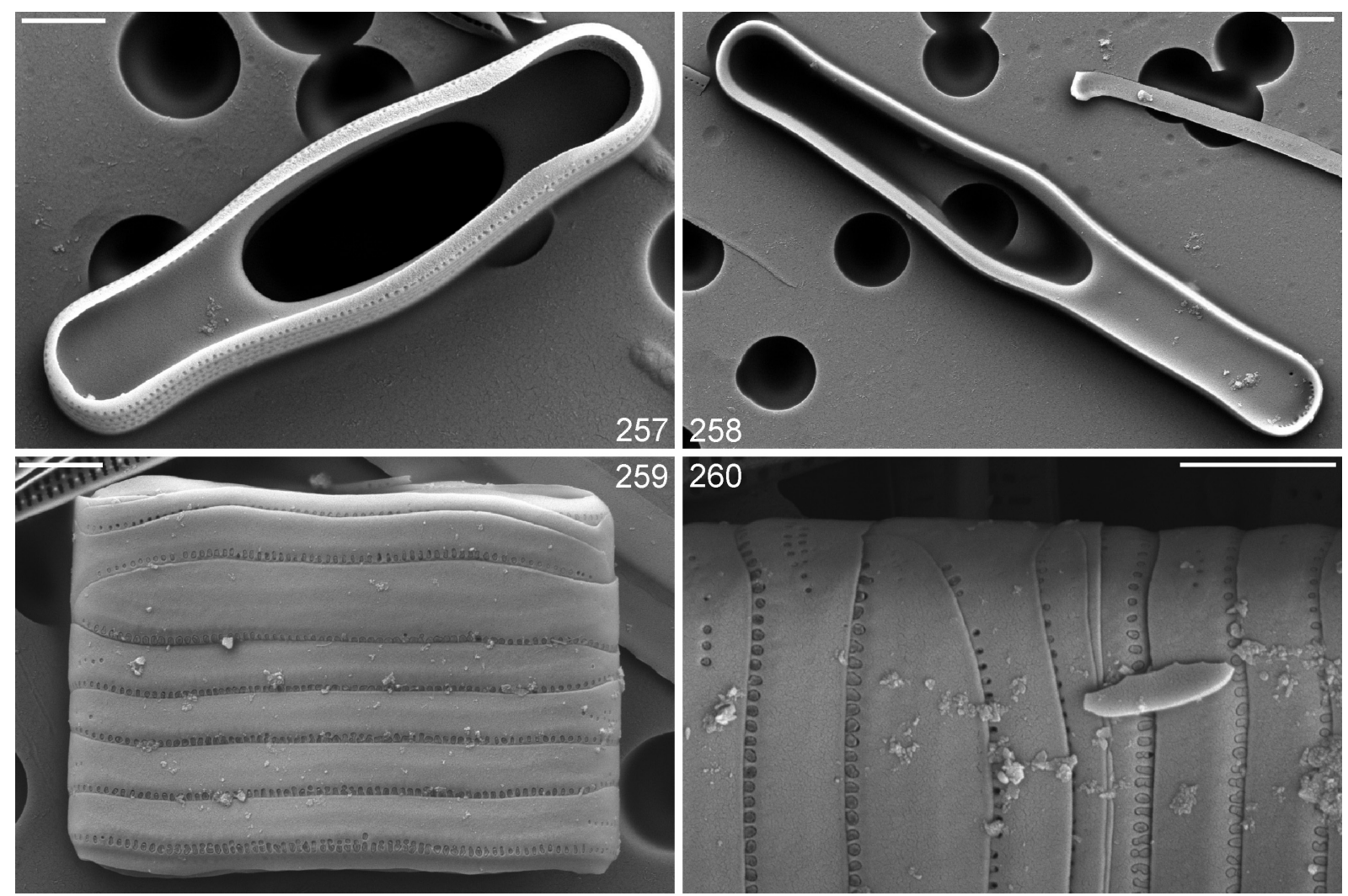

Figs 257-260. Tabellaria procera sp. nov., type material (from Cazaux Lake, La Teste-de-Buch, Nouvelle Aquitaine Region, France) : (257260) SEM views; $(257,258)$ entire copula views; (259) entire frustule in girdle view; (260) close-up of girdle bands ornamentation. Scale bars $2 \mu \mathrm{m}$.

peat bog in the Black Forest Mountains, located at an altitude of $1200 \mathrm{~m}$ a.s.l.. The Black Forest and Vosges Mountains are located on both sides of the Upper Rhine Valley. Its diatom assemblage is highly dominated by acidophilous taxa on granitic bedrocks. Abundant are Carex spp. and Menyanthes trifoliata L. (Gentianaceae) as indicator plants.

\section{Tabellaria koppeniana sp. nov. (Figs 191-209)}

Synonyms: Tabellaria flocculosa var. linearis sensu Koppen 1975, p. 243, figs 2, 3, 11, 18-22; Tabellaria flocculosa var. linearis Koppen sensu Camburn \& Charles 2000, pl. 10, figs 14-20.

Description: Valve outline generally linear, with a weakly inflated central part, gradually tapering towards the distinctly capitate ends (Figs 191-199). Apices in general more or less truncated, never broadly rounded as in most Tabellaria species (with the exception of $T$. fenestrata). Valve dimensions $(\mathrm{n}=30)$ : Length $60-127$ $\mu \mathrm{m}$, width (central area) 5.0-6.5 $\mu \mathrm{m}$, length/width ratio 12.0-20.9. Axial area very narrow to almost non-existent. One small, punctiform rimoportula visible in the central area, halfway between the axial area and the valve margin. Internally, rimoportula slit-like with two raised rims (Fig. 208). Striae mostly in opposite position, although in several valves alternating striae likewise observed, 16-19 in $10 \mu \mathrm{m}$. Areolae indiscernible in LM, rimmed in SEM (Figs 207, 209), especially near the valve margin, about 50 in $10 \mu \mathrm{m}$. Apical porefield composed of several regular apical rows of finer mucilage pores (Fig. 205) present at both apices (Fig. 205). Marginal row of small spines present, inserted on virgae (Fig. 209). Copulae open (Figs 200, 201).

Comparison with other Holarctic Tabellaria spp.: Based on valve outline, only Tabellaria procera $\mathrm{sp}$. nov. has a comparable weakly inflated central part. Both taxa can however be separated based on valve length as T. procera possesses significantly shorter valves (max. length $=43 \mu \mathrm{m}$ vs. $60-127 \mu \mathrm{m}$ in T. koppeniana) (see Figs 191-199, 210-244). Moreover $T$. procera has only weakly inflated, subcapitate apices whereas T. koppeniana has typically truncated but clearly capitate apices. The length/width ratio in T. procera is 2.6-11.5 while T. koppeniana has a L/W ratio of 12.0-20.9. The type population of Tabellaria flocculosa from Norway and other comparable T. flocculosa populations have a considerably much more inflated central area, with a length/ width ratio of approximately 2.0-10.0 (vs. 12.0-20.9 in T. koppeniana). Planktonic populations of T. flocculosa sometimes display a similar L/W ratio of ca. 12.5-21 but they can be distinguished by narrower valves proximally, 3.5-4 (vs. 5.0-6.5 in T. koppeniana) and distally about 3 (vs. 3-5) $\mu \mathrm{m}$ (see CAMBURN \& Charles 2000, pl. 10, figs 1-7).

Taxonomical comment: From a recent, more critically taxonomical point of view, an infraspecific rank for this species within $T$. flocculosa seems no longer appropriate. 
The type population from Sweden represents without doubt an independent species. However, a transfer of the epithet linearis, given by KoPPEN (1975), is less desirable as it may prove ambiguous. Used at species rank, it might give rise to new uncertainties among several resembling clusters of Tabellaria flocculosa sensu lato (e.g. KopPEN 1975, figs 37-43 as Group IIIp). KoPPEN (1975) described the valves of his groups II (T. fenestrata) and III (T. flocculosa var. flocculosa) as "linear". Based on the excellent documentation made by Koppen, we believe that both populations belong to the same taxon. However, if future DNA studies show that they are not conspecifics, then further nomenclatural problem will be absent. The elder infraspecific name has no priority according to the rules of the International Code of Nomenclature.

Holotype: BR-4624 (Meise Botanic Garden, Belgium), microscopic slide and preserved sample (treated material). Type locality: Rattån, Sweden (2254'19"E, 60²3'12"N), coll. date 08/09/2005, leg. P. Andersson.

Etymology: The new species is dedicated to J.D. Koppen who originally described T. flocculosa var. linearis in 1975. Distribution and ecology: Up to recently T. koppeniana is known from Scandinavia (Sweden), from the Austrian Alps (personal observations), from the Northeastern United States of America (e.g. Koppen 1975; CAMBURN \& Charles 2000; Siver et al. 2005) and Canada (Poulin et al. 1984; LANGE-Bertalot 1988; ZimmermanN et al. 2010). More locations may be expected in the future. The type locality (Rattån) is a small river located in central Sweden (village of Kristinefors), close to the border of Norway. The following environmental values were measured on 16 August 2005 from Rattån River (type): water temperature $18.5^{\circ} \mathrm{C}, \mathrm{pH} 6.48$, conductivity 19 $\mu \mathrm{S} . \mathrm{cm}^{-1}$, Kjeldhal nitrogen $9 \mu \mathrm{g} .1^{-1}$ and total phosphorus $8 \mu \mathrm{g} . \mathrm{l}^{-1}$. At type location in Sweden it is associated with Tabellaria flocculosa s. str., T. hercynica sp. nov., Frustulia saxonica, F. crassinervia, F. erifuga Lange-Bertalot et Krammer, Brachysira neoexilis Lange-Bertalot, Eunotia incisa, E. geniculata Hustedt, E. eurycephala (Grunow) Nörpel-Schempp et Lange-Bertalot, Semiorbis hemicyclus (Ehrenberg) R.M.Patrick, Encyonema neogracile Krammer, Navicula angusta Grunow, N. heimansioides Lange-Bertalot, which are all considered to be indicators of low alkalinity moderately acid, low conductivity waters.

\section{Tabellaria procera sp. nov. (Figs 210-260)}

Description: Frustules rectangular in girdle view (Figs 249, 259). Several closed copulae (ranging from a few to more than 20) possessing septa at one or both poles (Figs 245-248). Occasionally copulae laterally open and narrower than the others (Fig. 259). One (or two in case of valvocopulae) apical rows of areolae, externally covered by individual hymenes, present at the edges of the copulae (Fig. 259). Occasionally, incomplete rows of pores visible at the apices of the copulae (Figs 259, 260). Valves lanceolate to linear-lanceolate, becoming linear in the longest valves, with a weakly swollen central part and bluntly rounded to subcapitate, rarely almost capitate apices (Figs 210-244). Valve dimensions ( $\mathrm{n}=40)$ : length $17.0-43.0 \mu \mathrm{m}$, width (central part) 3.5-5.5 $\mu \mathrm{m}$, length/width ratio 2.6-11.5. Axial area narrow to very narrow, less than $1 \mu \mathrm{m}$ wide. Central area indistinctly set off, irregularly shaped. A single rimoportula present in the central area, situated at the end of one of the central striae (Figs 251, 256) or within it (Figs 252, 254). Apical porefields large (Fig. 255), composed of a dense pattern of small pores, arranged in several rows, present on both apices (Fig. 251). Striae almost parallel, (mostly) opposite or alternating position on either side, becoming more radiate towards the apices, 16-21 in 10 $\mu \mathrm{m}$. Areolae barely discernible in LM, in SEM 50-55 in $10 \mu \mathrm{m}$. Irregular series of marginal spines located at the valve face/mantle junction on either side, inserted on the virgae (Fig. 251). Internally, rimoportula clearly labiate (Figs 252, 254).

Comparison with other Holarctic Tabellaria spp.: Tabellaria procera can easily be separated from other taxa because it possesses narrower valves $(3.5-5 \mu \mathrm{m})$, except for the few slender specimens of T. flocculosa and T. koppeniana (Fig. 1). Even in those rare cases where the widths are similar, those two species can be differentiated from $T$. procera because $T$. koppeniana has a length/width ratio often more than twice higher (see Fig. 1 and differential diagnosis under T. koppeniana) and T. flocculosa has an angular proximal inflation and more capitate apical inflations (Figs 35-84).

Holotype: BR-4625 (Meise Botanic Garden, Belgium), microscopic slide and preserved sample (raw material in ethanol).

Type locality: Cazaux Lake, La Teste-de-Buch (Nouvelle Aquitaine Region, France) ( $\left.1^{\circ} 11^{\prime} 58^{\prime \prime} \mathrm{O}, 44^{\circ} 29^{\prime} 7^{\prime \prime N}\right), 10$ August 2016.

Etymology: The specific epithet is derived from the Latin adjective procerus ('elongated, slender') indicating the unique slender valve shape, atypical for the genus Tabellaria.

Distribution and ecology: Only two populations of $T$. procera are known: the type population from the Cazaux Lake and a population in the Arjuzanx Lake, both located in the Landes Department in southwestern France. The following environmental values were measured on 02 August 2016 from Cazaux Lake (type): water temperature $25^{\circ} \mathrm{C}$, pH 6.95, conductivity $203 \mu \mathrm{S} . \mathrm{cm}^{-1}$, Kjeldhal nitrogen $0.3 \mathrm{mg} .1^{-1}, \mathrm{NH}_{4}^{+} 0.02 \mathrm{mg} . \mathrm{l}^{-1}, \mathrm{NO}_{2}^{-} 0.01 \mathrm{mg} . \mathrm{l}^{-1}$, $\mathrm{NO}_{3}^{-} 0.5 \mathrm{mg} . \mathrm{l}^{-1}$, total phosphorus $0.01 \mathrm{mg} . \mathrm{l}^{-1}$, dissolved organic carbon $5.9 \mathrm{mg} . \mathrm{l}^{-1}$, dissolved oxygen $8.56 \mathrm{mg} . \mathrm{l}^{-1}$, dissolved oxygen saturation $103 \%$. The diatom flora in the epiphytic sample was dominated by Tabellaria procera, Achnanthidium minutissimum (Kützing) Czarnecki, Cymbella cymbiformis C.Agardh, Fragilaria gracilis Østrup, F. perdelicatissima Lange-Bertalot et Van de Vijver, Halamphora oligotraphenta (Lange-Bertalot) Levkov, Mastogloia sterijovskii Pavlov, Jovanovska, C.E.Wetzel, Ector et Levkov and Nitzschia archibaldii Lange-Bertalot. 
Tabellaria andina (Lange-Bertalot) Lange-Bertalot stat. nov.

Basionym: Tabellaria flocculosa var. andina LANGE-Bertalot 1993, Bibliotheca Diatomologica 27, p. 160, 161, pl. 11, figs 1-9.

Differential description vs. Tabellaria flocculosa (Roth) Kützing: Valve outline roughly resembling T. flocculosa but only for the smaller and medium-sized valve in the valve diminution series. Longer T. flocculosa valves (type population from Norway) differ by less widely inflated central part: $4.0-9.0 \mu \mathrm{m}$ vs. $9.5-11 \mu \mathrm{m}$ in $T$. andina $(\mathrm{n}=30)$. Length/width therefore less extended for T. andina, 3.7-5.9 vs. 2.0-10.0 for T. flocculosa. Central parts of the valves are abruptly rhombically set off in $T$. andina vs. rather gradually set off in minor and medium-sized valves and even more so in longer valves of $T$. flocculosa. Valve dimensions for $T$. andina: length 35-65 $\mu \mathrm{m}$; width (apices) 4-5 $\mu \mathrm{m}$, width (connection parts between central part and apices) $2-3 \mu \mathrm{m}$. Axial area distinct, ca. $0.5 \mu \mathrm{m}$ wide. Central area variable in shape and size. Striae opposite or alternating, 15-18 in $10 \mu \mathrm{m}$. SEM external and internal view in LANGE-BERTALOT (1993, pl. 11, figs 7-9). Areolae 50-60 in $10 \mu \mathrm{m}$. One single rimoportula situated in the central part, extended transapically in between areolae of a stria. Marginal spines acutely conical in shape, located circumferentially on virgae at valve face/mantle junction. All the latter mentioned features barely different from T. flocculosa. Copulae with unequal septa at both apices. Pleurae lacking septa, open at one apex.

Holotype: Praep. AM-S 127, Coll. Lange-Bertalot (FR). Type locality: Laguna Negra, Venezuela, lake in the Andes, $3300 \mathrm{~m}$ a.s.1. (leg. Ute Rumrich). The species is present with mass development in the moderately acidic lake, $\mathrm{pH}$ 5.0, low conductivity.

Distribution and ecology: Only observed as yet from its type location in the High Andes of Venezuela.

Taxonomical remarks: Based on more critical observations of the morphological features and the results of this paper, the original status of this taxon should be revised compared to the point of view in LANGE-BERTALOT (1993). An independent species appears more appropriate than the infraspecific rank of the "catch call" taxon Tabellaria flocculosa. The most resembling population in Europe is T. flocculosa from Lake Servière, France (see supplementary material). The latter is, however, distinguished by less widely extended proximal inflations, 5.9-7.4 (vs. 9-11) $\mu \mathrm{m}$.

\section{Discussion}

Morphometric measurements alone as shown in Figure 1 are not sufficient to correctly separate all taxa and they must be complemented with valve shape description. They are nevertheless useful to separate some species (Fig. 1) by their width (T. procera, T. ventricosa or $T$. valdeventricosa), length / width ratio ( $T$. fenestrata and $T$. koppeniana) or proximal / apical width ratio (T. fenestrata,
T. koppeniana and also T. hercynica as long as the mean value of a population is considered). The main limitation for a discriminative use of those morphometrical measures comes from the great variability observed in the type material of $T$. flocculosa, both in measurements and in the shape of the small specimens (Fig. 1). However, this variability is less visible at the level of the ultrastructure (see additional SEM plate of the type in supplementary materials), SEM Fig. 86 showing the extreme case of one of the most atypical small valves (e.g. LM Figs 41, $42,46,50)$. No other population of $T$. flocculosa that we had observed show as much morphological plasticity as the type (See supplementary material Figs S11-S61). Even other species with wide length amplitude such as T. ventricosa and T. koppeniana kept more constant valve shape through the cell division cycle (respectively Figs 89-110, 191-199). Additionally, other characters seem variable between different populations such as spine shape (always sharp in type material but a population was found with flat-headed spines, Fig. S39) or the rimmed character of areolae.

Such variability suggests phenotypic expressions, known to influence morphometric data and the shape or ultrastructure of valves in other genera (e.g. HÅKANSSON \& KorhOla 1998; HÅKANSSON \& CHEPURNOV 1999; BERTRAND et al. 2003; Trobajo et al. 2011). Theriot \& LADEWSKI (1986) analysed the shape variation of specimens from the neotype of $T$. flocculosa by computer-assisted morphometric techniques, and they proposed nonexclusive hypothesis for the increase of shape variability in small specimens: different genetic entities involved, strict shape control for specimens longer than $35 \mu \mathrm{m}$ and environmental variation during the period of development.
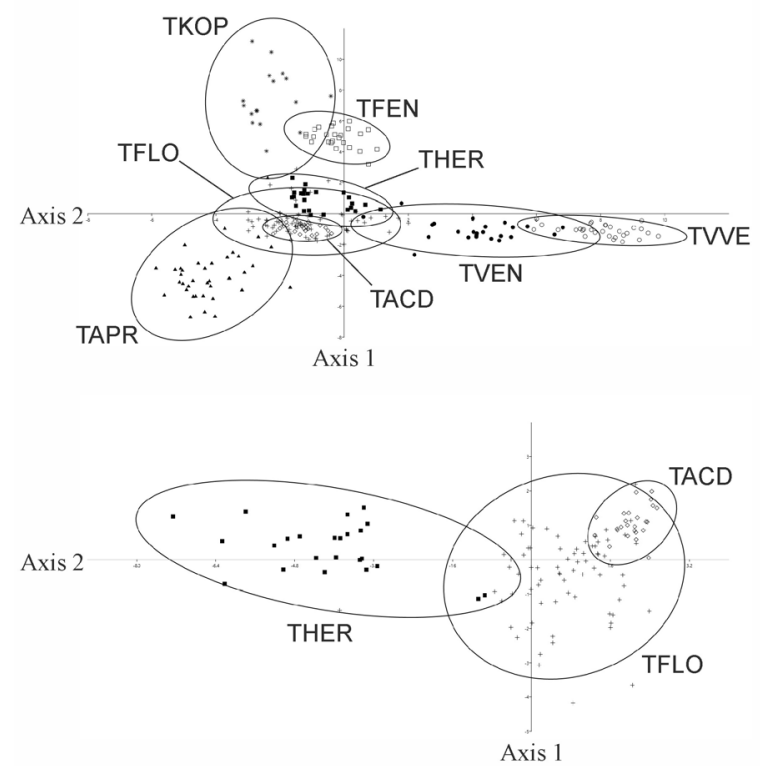

Fig. 261. Comparison of the type populations. Data fitted to $95 \%$ confidence ellipses. LDA plot of the outline descriptors resulting from the analysis using SHERPA software. A LDA was made for all species studied (upper graph) and another considering only the $T$. flocculosa species complex (lower graph). 
Their first hypothesis is still valid because we were not able to collect fresh material from the type locality for DNA analysis. Moreover, LYNGBYE (1819) described the sampling as "In fluviis ad officinam ferrariam Naes Norvegiae" ("in river near ironwork Naes Norvegiae"). It was an ironwork and mechanical workshop operating from 1665 to 1959 . We therefore cannot exclude the presence of metals in the environment, which could be responsible for the most atypical and slightly asymmetrical forms found in the type material (Figs 41, 42, 46, 50) as shown in GonÇALVES et al. (2019, fig. 4). Later, Mou \& Stoermer (1992) randomised and analysed 490 North American Tabellaria specimens to separate shape groups with Fourier descriptors and showed that it exhibits less ecophenotypic plasticity in natural environment than other diatoms genera. They also concluded that the valve shape is a crucial character in Tabellaria taxonomy and is still reliable even with the interference of size and shape change induced by cell division. Further studies of the taxonomy of this group by culturing North American populations were stopped due to the phenotypic expressions problem (P.B. Hamilton, pers. comm.). MANN \& Chepurnov (2004) have highlighted that some extreme examples of phenotypic plasticity demonstrated in culture may have no real relevance to diatom systematics and that classification by morphology is not endangered by those examples. So in our opinion, morphological and ecological studies of carefully selected populations are still reliable. To enforce this hypothesis, computer assisted outline analysis of the type materials of the eight species were made. Linear discriminate analysis of those data shows that the species studied, although having a globally similar outline, are well separated by these morphology descriptors (Fig. 261). Moreover, Kruskal-Wallis test for equal medians were made for each descriptor and always showed significant difference between medians of species. Mann-Whitney pair test with Bonferroni correction were made and also highlighted significant differences between species for most of the descriptors (e.g. in Table 3). However, genetic studies of those taxa as suggested by MANN (2010) and Cox (2014) could attest or invalid morphological hypothesis, but unfortunately we couldn't conduct them at the present time.

The analysis of the type material of $T$. fenestrata, T. flocculosa and T. ventricosa confirm their status as two independent and differentiable species, at least from a morphological point of view. The comparison of this type material with European populations allowed the description of five new species, each presenting different morphological characteristics and ecology: Tabellaria acidodelicata sp. nov., Tabellaria hercynica sp. nov., Tabellaria koppeniana sp. nov., Tabellaria procera sp. nov. and Tabellaria valdeventricosa sp. nov. Additionally, Tabellaria flocculosa var. andina was re-analysed and based on the results, the variety was raised to species level as Tabellaria andina (Lange-Bertalot) LangeBertalot stat. nov.

With this paper, we tried to solve part of the uncertainties in the morphological identification of the Tabellaria flocculosa/ventricosa complex. There is, however, another species that is occasionally observed in European waters Tabellaria quadriseptata Knudson. Unfortunately, we were not able to study the type material of this species and no population among the hundreds studied corresponds perfectly with its original description (KNUDSON 1952): a valve outline similar to $T$. fenestrata with the three inflations approximately equal in width, four septa in girdle view and colonies with "zigzag" shape on raw material. FLOWER \& BATTARBEE (1985) studied this material in LM but unfortunately compared it with $T$. flocculosa because of similar zigzag-shaped colonies instead of $T$. fenestrata which has a similar valve outline and dimensions. They also focused on the presence of evenly distributed long marginal spines (around $1 \mu \mathrm{m}$ ) in T. quadriseptata instead of irregularly distributed shorter spines $(<0.5 \mu \mathrm{m})$ in other species, but again we couldn't find this feature in any of the examined populations. Moreover, the distinctive criterion mentioned by KNUDSON (1952, p. 435) based on the position of the rimoportula in the central inflation seems not to be discriminating because its location is very variable in the type material (Figs 2-11) and other studied populations of T. fenestrata (e.g. Figs 22-29). Another distinctive feature provided by KNUDSON (1952, p. 425) would be that the apices are not capitate compared to those of $T$. fenestrata but the difference is not clear in her original drawings on fig. 1. Finally, $T$. fenestrata was identified in a lot of environments similar to those where Flower \& BATTARBEe (1985) identified T. quadriseptata, i.e. dystrophic and oligotrophic lakes and ponds with acidic waters, and not in eutrophic waters as suggested by KNUDSON (1952, p. 425). As long as the type material has not been studied again, the name T. quadriseptata should be used with caution as it may be conspecific with $T$. fenestrata and differs only in the shape of the colonies, as originally thought by SMITH (1856, pl. 43, fig. 317) whose material was used as type for T. quadriseptata. Finally, Tabellaria pseudoflocculosa H.Kobayasi ex Mayama in Kobayasi et al. (KoBAYASI et al. 2006) should probably be considered as a synonym of T. quadriseptata, as its description are almost identical to the original T. quadriseptata description. Kobayasi was probably not aware of Knudson's publication as it was not cited in the publication of T. pseudoflocculosa (KoBAYASI et al. 2006). Analysis of the type material of $T$. quadriseptata and a new comparison with $T$. fenestrata will be necessary to clarify this possible conspecificity.

Finally, we think that future DNA studies of those taxa will probably be the key to advance further in understanding the complexity of the genus Tabellaria.

\section{ACKNOWLEDGEMENTS}

Parts of the results of this paper have been presented during the $12^{\text {th }}$ Central European Diatom Meeting, 26-27 March, 2019 in Belvaux, Luxembourg, and during the 38ème Colloque de l'Association des Diatomistes de Langue Française (ADLaF), 10-12 September, 2019 in Dijon, France. Funding for this research was partly provided in the framework of the DIATOMS project (LIST - Luxembourg Institute 
of Science and Technology). We thank Mrs Delphine Sagnet from DREAL Nouvelle Aquitaine for the Cazaux Lake's sample donation and Mrs Amelie Jarlman (Lund, Sweden) for the Rattan's sample donation. Mrs Petra Ballings is also thanked for helping with the SEM observations of T. koppeniana at Meise Botanic Garden (Belgium). Dr Nina Lundholm and Dr Christian Lange (Copenhagen, Denmark) are thanked from sending us the type material of Diatoma fenestrata Lyngbye. Moreover, we thank the referee Mr Paul B. Hamilton and the editor Dr Alka Poulickova for their constructive remarks and suggestions that greatly improved this manuscript.

\section{REFERENCES}

Antoniades, D.; Hamilton, P.B.; Douglas, M.S.V. \& Smol, J.P. (2008): Diatoms of North America: The freshwater floras of Prince Patrick, Ellef Ringnes and northern Ellesmere Islands from the Canadian Arctic Archipelago. - Iconographia Diatomologica 17: 1-649.

Bertrand, C.; Franquet, E.; Fayolle, S., \& Cazaubon, A. (2003). A new approach of the biodiversity: morphological plasticity of a freshwater diatom. - Comptes Rendus Biologies 326: 107-120.

Camburn, K.E. \& Charles, D.F. (2000): Diatoms of lowalkalinity lakes in the northeastern United States. Academy of Natural Sciences of Philadelphia, Special Publication 18: 1-152.

Cantonati, M.; Angeli, N.; Bertuzzi, E.; Spitale, D. \& Lange-Bertalot, H. (2012): Diatoms in springs of the Alps: spring types, environmental determinants, and substratum. - Freshwater Science 31: 499-524.

Cox, E.J. (2014). Diatom identification in the face of changing species concepts and evidence of phenotypic plasticity. - Journal of Micropalaeontology 33: 111- 120.

DeColibus, D. (2013a): Tabellaria fenestrata. - In Diatoms of North America. Retrieved August 13, 2020, from https://diatoms.org/species/tabellaria_fenestrata.

DeColibus, D. (2013b): Tabellaria flocculosa. - In Diatoms of North America. Retrieved August 13, 2020, from https://diatoms.org/species/tabellaria_flocculosa.

Dolan, J.R. (2019): Unmasking "The Eldest Son of The Father of Protozoology": Charles King. - Protist 170: 374-384.

Ector, L.; Wetzel, C.E.; Novais, M.H. \& GullLard, D. (2015): Atlas des diatomées des rivières des Pays de la Loire et de la Bretagne. - 661 pp., Direction Régionale de l'Environnement, de l'Aménagement et du Logement Pays de la Loire, Nantes.

EHRENBERG, C.G. (1840): Characteristik von 274 neuen Arten von Infusorien. - Bericht über die zur Bekanntmachung geeigneten Verhandlungen der Königlich-Preussischen Akademie der Wissenschaften zu Berlin 1840: 197-219.

FABRI, R. \& LECLERCQ, L. (1984): Etude écologique des rivières du nord du massif Ardennais: flore et végétation de diatomées et physico-chimie des eaux. 1. Contexte mésologique. Méthodes. Analyses physico-chimiques. Synthèse taxonomique, écologique et floristique. Iconographie. Bibliographie. - 379 pp., 33 pls, Station Scientifique des Hautes-Fagnes, Robertville.

Flower, R.J. \& Battarbee, R.W. (1985): The morphology and biostratigraphy of Tabellaria quadriseptata (Bacillariophyceae) in acid waters and lake sediments in Galloway, Southwest Scotland. - British Phycological Journal 20: 69-79.

Genkal, S.I. \& Chekryzheva, T.A. (2016): To morphology and taxonomy of Tabellaria flocculosa (Bacillariophyta). - Transactions of I. D. Papanin Institute for Biology of Inland Waters 76: 5-24.

Germain, H. (1987): Les Tabellaria (Bacillariophyceae) dans l'Ouest de la France. - Cahiers de Biologie Marine 28: 291-295.

Gonçalves, S., Almeida, S.F.P., Figueira, E. \& Kahlert, M. (2019): Valve teratologies and $\mathrm{Chl} c$ in the freshwater diatom Tabellaria flocculosa as biomarkers for metal contamination. - Ecological Indicators 101: 476-485.

HÅKANSSON, H. \& CHEPURNov, V. (1999): A study of variation in valve morphology of the diatom Cyclotella meneghiniana in monoclonal cultures: effect of auxospore formation and different salinity conditions. - Diatom Research 14: 251-272.

HÅKansson, H. \& Korhola, A. (1998): Phenotypic plasticity in the diatom Cyclotella meneghiniana or a new species? - Nova Hedwigia 66: 187-196.

Hammer, Ø.; Harper, D.A.T. \& Ryan, P.D. (2001): PAST: Paleontological statistics software package for education and data analysis. - Palaeontologia Electronica 4: 1-9.

Hassal, A.H. (1845): A History of the British Freshwater Algae, including description of the Desmideae and Diatomaceae. Vol. 1. - 447 pp., London.

Heudre, D.; Wetzel, C.E.; Moreau, L. \& Ector, L. (2018): Diatoms of Gérardmer Lake (Vosges, France). - Nova Hedwigia, Beihefte 146: 253-277.

Hofmann, G.; Werum, M. \& Lange-Bertalot , H. (2011): Diatomeen im Süßwasser-Benthos von Mitteleuropa. Bestimmungsflora Kieselalgen für die ökologische Praxis. Über 700 der Häufigsten Arten und ihre Ökologie. - 908 pp., A.R.G. Gantner Verlag K.G., Rugell, distributed by Koeltz Scientific Books, Königstein.

Kloster, M.; KAUER, G. \& BeszTERI, B. (2014): SHERPA: an image segmentation and outline feature extraction tool for diatoms and other objects. - BMC Bioinformatics 15: 218

Knudson, B.M. (1952): The diatom genus Tabellaria I. Taxonomy and morphology. - Annals of Botany 16: 421-440.

Kobayasi, H.; IdeI, M.; Mayama, S.; Nagumo, T. \& Osada, K. (2006): H. Kobayasi's Atlas of Japanese Diatoms based on electron microscopy. -531 pp., Uchida Rokakuho Publishing Co., Ltd., Tokyo.

Koppen, J.D. (1975): A morphological and taxonomic consideration of Tabellaria (Bacillariophyceae) from the northcentral United States. - Journal of Phycology 11: 236-244.

Krammer, K. \& LANGe-Bertalot, H. (1991): Bacillariophyceae. 3. Teil: Centrales, Fragilariaceae, Eunotiaceae. - In: Ettr, H.; Gerloff, J.; Heynig, H. \& Mollenhauer, D. (eds): Süßwasserflora von Mitteleuropa. Band 2/3. - 576 pp., Gustav Fischer Verlag, Stuttgart - Jena.

KüTZING, F.T. (1844): Die kieselschaligen Bacillarien oder Diatomeen. - 152 pp., Nordhausen: zu finden bei W. Köhne.

Lange-Bertalot, H. (1988): Die Gattung Tabellaria unter besonderer Berücksichtigung von Tabellaria ventricosa Kützing (Bacillariophyceae). - Nova Hedwigia 46: 413-431.

LANGe-Bertalot, H. (1993): 85 Neue Taxa und über 100 weitere neu definierte Taxa ergänzend zur Süßwasserflora von Mitteleuropa Vol. 2/1-4. - Bibliotheca Diatomologica 27: 1-454.

Lange-Bertalot, H. (2001): Navicula sensu stricto. 10 Genera separated from Navicula sensu lato. Frustulia. - Diatoms of Europe 2: 1-526. 
Lange-Bertalot, H.; Hofmann, G.; Werum, M. \& Cantonati, M. (2017): Freshwater benthic diatoms of Central Europe: Over 800 common species used in ecological assessment. English edition with updated taxonomy and added species. - In: Cantonati, M.; Kelly, M.G. \& Lange-Bertalot, H. (eds). - 942 pp., Koeltz Botanical Books, Schmitten-Oberreifenberg.

LyngBYe, H.C. (1819): Tentamen Hydrophytologiae Danicae Continens omnia Hydrophyta Cryptogama Daniae, Holsatiae, Faeroae, Islandiae, Groenlandiae hucusque cognita, Systematice Disposita, Descripta et Iconibus Illustrata, Adjectis Simul Speciebus Norvegicis. - 248 pp., Hafniae.

ManN, D.G. (2010): Discovering diatom species: is a long history of disagreements about species-level taxonomy now at an end? - Plant Ecology and Evolution 143: 251-264.

MAnN, D.G. \& ChePurnov, V. A. (2004): What have the Romans ever done for us? The past and future contribution of culture studies to diatom systematics. - Nova Hedwigia 79: 237-291.

Mou, D. \& Stoermer, E. F. (1992): Separating Tabellaria (Bacillariophyceae) shape groups based on Fourier descriptors. - Journal of Phycology 28: 386-395.

Peeters, V. \& Ector, L. (2017): Atlas des diatomées des cours d'eau du territoire bourguignon. Volume 1: Centriques, Araphidées. - 309 pp., Direction Régionale de l'Environnement, de l'Aménagement et du Logement Bourgogne-Franche-Comté, Dijon. http://www. bourgogne-franche-comte.developpement-durable. gouv.fr/atlas-des-diatomees-des-cours-d-eau-duterritoire-a7004.html

Poulin, M.; Berard-Therriault, L. \& Cardinal, A. (1984): Les diatomées benthiques de substrats durs des eaux marines et saumâtres du Québec. 2. Tabellarioideae et Diatomoideae (Fragilariales, Fragilariaceae). Naturaliste Canadien 111: 275-295.

R Core Team (2019): R: A language and environment for statistical computing. - R Foundation for Statistical Computing, Vienna, Austria. https://www.R-project.org/.

Roтн, A.W. (1797): Catalecta Botanica Quibus Plantae Novae Et Minus Cognitae Describuntur Atque Illustrantur. Fasc. 1. -244 pp., Lipsiae.

Round, F.E.; Crawford, R.M. \& Mann, D.G. (1990): The diatoms. Biology \& morphology of the genera. -747 pp., Cambridge University Press, Cambridge.

Siver, P.A.; Hamilton, P.B.; Stachura-Suchoples, K. \& Kociolek, J.P. (2005): Diatoms of North America: The freshwater flora of Cape Cod, Massachusetts, U.S.A. - Iconographia Diatomologica 14: 1-463.

Smith, W. (1856): A synopsis of the British Diatomaceae: with remarks on their structure, functions and distribution; and instructions for collecting and preserving specimens. Vol. 2. - 107 pp., pls 32-67, London: John Van Voorst.

Theriot, E. \& LADEwSKI, T. B. (1986): Morphometric analysis of shape of specimens from the neotype of Tabellaria flocculosa (Bacillariophyceae). - American Journal of Botany 73: 224-229.

Trobajo, R.; Rovira, L.; Mann, D.G. \& Cox, E.J. (2011): Effects of salinity on growth and on valve morphology of five estuarine diatoms. - Phycological Research 59: 83-90.

VanLandingham, S.L. (1978): Catalogue of the fossil and recent genera and species of diatoms and their synonyms: Part VII: Rhoicosphenia through Zygoceros. - pp. 3606-4241, J. Cramer, Vaduz.

ZACH, O. (1979): Planktonuntersuchungen am Wolfgangsee und am Schwarzensee. - ÖKO.L Zeitschrift für Ökologie, Natur- und Umweltschutz 4: 7-11.

Zimmermann, C.; Poulin, M. \& Pienitz, R. (2010): Diatoms of North America: The Pliocene-Pleistocene freshwater flora of Bylot Island, Nunavut, Canadian High Arctic. - Iconographia Diatomologica 21: 1-407.

Supplementary material

The following supplementary material is available for this article:

Figs S1-S10. Tabellaria fenestrata (Lyngbye) Kützing. Sample from unnamed pond near Heckental, Grand Est Region, France.

Figs S11-S16. Tabellaria flocculosa (Roth) Kützing. Type material (Diat. Spec. typ. No. 50 "In Aqua Dulci Naes Norvegia". Eulenstein collection, Meise Botanic Garden, Belgium).

Figs S17-S35. Tabellaria flocculosa (Roth) Kützing. Sample from Servières Lake, Auvergne Region, France.

Figs S36-S39. Tabellaria flocculosa (Roth) Kützing. Sample from Servières Lake, Auvergne Region, France.

Figs S40-S61. Tabellaria flocculosa (Roth) Kützing. Sample from Blackbirds Lake, Grand-Est Region, France.

This material is available as part of the online article (http:// fottea.czechphycology.cz/contents)

(C) Czech Phycological Society (2021)

Received October 13, 2020

Accepted April 14, 2021 